NBER WORKING PAPER SERIES

\title{
UNDERSTANDING THE GAINS FROM WAGE FLEXIBILITY: THE EXCHANGE RATE CONNECTION
}

\author{
Jordi Galí \\ Tommaso Monacelli \\ Working Paper 22489 \\ http://www.nber.org/papers/w22489 \\ NATIONAL BUREAU OF ECONOMIC RESEARCH \\ 1050 Massachusetts Avenue \\ Cambridge, MA 02138 \\ August 2016
}

We have benefited from comments by Stephanie Schmitt-Grohé, Emmanuel Farhi, Marty Eichenbaum (editor), two anonymous referees, and participants at seminars and conferences at CREI-UPF, NBER Summer Institute (IFM), Bonn, Pavia, Banco de Portugal, London Business School, and UC Berkeley, Irish Economic Association, CEMFI, Jerusalem, National Bank of Slovakia, National Bank of Serbia, KU Leuven, ILO Geneva, and Tilburg University. Michele Fornino, Francesco Giovanardi, Chiara Maggi and Cristina Manea provided excellent research assistance. We thank the Fondation Banque de France for financial support. Part of this work has been conducted while Monacelli was visiting the Department of Economics at Columbia University, whose hospitality is gratefully acknowledged. The views expressed herein are those of the authors and do not necessarily reflect the views of the National Bureau of Economic Research.

At least one co-author has disclosed a financial relationship of potential relevance for this research. Further information is available online at http://www.nber.org/papers/w22489.ack

NBER working papers are circulated for discussion and comment purposes. They have not been peer-reviewed or been subject to the review by the NBER Board of Directors that accompanies official NBER publications.

(C) 2016 by Jordi Galí and Tommaso Monacelli. All rights reserved. Short sections of text, not to exceed two paragraphs, may be quoted without explicit permission provided that full credit, including $(\odot$ notice, is given to the source. 
Understanding the Gains from Wage Flexibility: The Exchange Rate Connection

Jordi Galí and Tommaso Monacelli

NBER Working Paper No. 22489

August 2016

JEL No. E32,E52,F41

\title{
ABSTRACT
}

We study the gains from increased wage flexibility using a small open economy model with staggered price and wage setting. Two results stand out: (i) the effectiveness of labor cost reductions as a means to stimulate employment is much smaller in a currency union, (ii) an increase in wage flexibility often reduces welfare, more likely so in an economy that is part of a currency union or with an exchange rate-focused monetary policy. Our findings call into question the common view that wage flexibility is particularly desirable in a currency union.

\author{
Jordi Galí \\ Centre de Recerca en Economia Internacional (CREI) \\ Ramon Trias Fargas 25 \\ 08005 Barcelona \\ SPAIN \\ and NBER \\ jgali@crei.cat \\ Tommaso Monacelli \\ IGIER Università Bocconi \\ Via Roentgen 1 \\ 20136 Milano \\ Italy \\ tommaso.monacelli@unibocconi.it
}


The belief in the virtues of wage flexibility is widespread in policy circles. It manifests itself most clearly in the recurrent calls for wage moderation (or even outright wage cuts), issued by international policy institutions, and addressed to countries facing high unemployment. The Great Recession and the "crisis of the euro" have only reinforced those views.

The case for wage flexibility rests on its perceived role as a factor of macroeconomic stability. Thus, a decrease in wages is expected to offset, at least partly, the negative effects on employment (and output) of an adverse aggregate shock. Conversely, the presence of rigid wages tends to amplify the employment and output effects of those shocks, increasing macroeconomic instability. ${ }^{1}$

The role of wages as a cushion is viewed as being particularly important in the context of economies that have joined a currency union or adopted any other form of hard peg, for in those cases the exchange rate is no longer available as an adjustment mechanism. In the face of a shock that calls for a real exchange rate depreciation, a wage-based "internal devaluation" is warranted. The presence of wage rigidities, it is argued, will hinder that adjustment, and make it longer and more painful, by requiring, ceteris paribus, a higher rate of unemployment to bring about the needed adjustment in wages and prices. To the extent that wage flexibility acts as a substitute for exchange rate flexibility, it is viewed as particularly desirable in economies that have adopted a hard peg or joined a currency union. $^{2}$

Specifically, and in the face of an adverse shock, a reduction in domestic wages leads to a terms of trade depreciation, which may help stabilize aggregate demand, output and employment. We refer to that mechanism as the "competitiveness channel".

The previous conventional wisdom ignores, however, the fact that in economies with nominal rigidities the impact of wage adjustments on employment works to a large extent through its induced effect on the endogenous component of monetary policy, as the latter is loosened or tightened in response to lower or higher inflationary pressures. We refer to this mechanism as the "endogenous policy channel." Thus, and as argued in Galí (2013) in the context of a closed economy model, whether an increase in wage flexibility raises welfare depends on the monetary policy rule in place and, in particular, on the strength of the central bank's systematic response to inflation. If that response is weak, the benefits of increased wage flexibility in the form of more employment stability will be small and, in many cases, more than offset by the losses associated with greater volatility in price and wage inflation.

\footnotetext{
${ }^{1}$ See e.g. Hall (2005) and Shimer (2005, 2012) for a discussion of the role of wage rigidities in accounting for labor market fluctuations in the context of the search and matching model. Blanchard and Galí (2007, 2010) emphasize the policy tradeoffs generated by the presence of wage rigidities.

${ }^{2}$ The analysis of the interaction between wage rigidities and the exchange rate regime traces back to Friedman (1953). Recent research on the consequences of wage rigidity in currency unions can be found in Schmitt-Grohe and Uribe (2015) and Farhi et al. (2013).
} 
In the present paper we extend the analysis of the gains from wage flexibility to the case of an open economy, where both the competitiveness and endogenous policy channels coexist to a greater or lesser extent. In particular, we focus on the case of a small open economy that is part of a currency union or has adopted a hard peg. In that case, and in the absence of capital controls, the domestic interest rate will not deviate from its relevant foreign counterpart in the face of a variety of shocks that may call for terms of trade adjustment. As a result the "endogenous policy channel" will be muted, and so will be the effect of a labor cost adjustment on aggregate demand and employment.

Our analysis, based on a small open economy model with staggered price and wage setting, delivers two main findings. ${ }^{3}$

Firstly, we show that the impact of labor cost adjustments on employment is much smaller for an economy that is part of a currency union, compared to an economy with an autonomous monetary policy and a price stability mandate. Accordingly, and contrary to conventional wisdom, wage adjustments are particularly ineffective in a currency union.

Secondly, we show that an increase in wage flexibility often reduces welfare, and it is more likely to do so in an economy that belongs to a currency union or, more generally, in an economy whose monetary policy attaches a strong weight to the stabilization of the exchange rate. The previous finding is shown to be robust to a variety of changes in the model's assumptions. We identify an important qualification, however: an increase in wage flexibility is more likely to be welfare improving if accompanied by a simultaneous increase in price flexibility.

Taken as a whole, our findings call into question the robustness of the traditional view, often taken as self-evident, that wage flexibility is particularly desirable in an economy that has relinquished the exchange rate as an adjustment mechanism.

The remainder of the paper is organized as follows. In Section 1 we describe our baseline model. In Section 2 we analyze the role of the exchange rate regime in determining the effects of a labor cost reduction. Section 3 analyzes the effects of increased wage flexibility on welfare, and their relation to the exchange rate regime. Section 4 discusses the robustness of our findings to an extension of our model allowing for capital accumulation, indexation, imperfect pass-through, and a range of intermediate monetary regimes, among other features. Section 5 discusses the related literature. Section 6 concludes.

\footnotetext{
${ }^{3}$ Our framework builds on Galí and Monacelli (2005), which is extended to incorporate sticky wages, in addition to sticky prices. The resulting framework is similar to the one used in Campolmi (2012) and Erceg et al. (2009).
} 


\section{A Baseline New Keynesian Model of a Small Open Economy}

In this section we describe the key ingredients of the baseline model we use in our analysis of the gains from wage flexibility. Our model is one of a small open economy with staggered price and wage setting. It builds on the framework developed in Galí and Monacelli (2005), extending the latter by introducing sticky nominal wages (in addition to sticky prices), and three additional shocks (domestic demand, exports, and world interest rate) beyond the domestic technology shocks present in our earlier paper. ${ }^{4}$ As in Galí and Monacelli (2005) we assume that the size of the home economy is negligible relative to that of the world economy, which allows us to take world aggregates as exogenous. Furthermore, we assume that the law of one price holds, that financial markets (both domestic and international) are complete, and ignore capital accumulation. Since the model is relatively standard, we restrict our exposition below to a description of the main assumptions, while relegating most derivations to Appendix A.

In Section 4 below we examine the robustness of our results using an extension of our baseline model that allows for a variety of features ignored in the baseline model.

\section{$1.1 \quad$ Households}

We study a small open economy inhabited by a representative household. The household has a continuum of members, indexed by $j \in[0,1]$. Each household member is specialized in a differentiated occupation and supplies labor services in an amount $\mathcal{N}_{t}(j)$. Household preferences are given by

$$
E_{0} \sum_{t=0}^{\infty} \beta^{t} U\left(C_{t},\left\{\mathcal{N}_{t}(j)\right\} ; Z_{t}\right)
$$

where $C_{t}$ is a consumption index, and $Z_{t}$ is an exogenous preference shifter. Parameter $\beta \equiv \frac{1}{1+\rho} \in[0,1]$ is the discount factor.

Period utility $U$ is assumed to take the form

$$
U\left(C_{t},\left\{\mathcal{N}_{t}(j)\right\} ; Z_{t}\right)=\left(\log C_{t}-\frac{1}{1+\varphi} \int_{0}^{1} \mathcal{N}_{t}(j)^{1+\varphi} d j\right) Z_{t}
$$

with the consumption index $C_{t}$ defined by

$$
C_{t} \equiv \Upsilon\left(C_{H, t}\right)^{1-v}\left(C_{F, t}\right)^{v}
$$

\footnotetext{
${ }^{4}$ See, e.g. Campolmi (2012) and Erceg et al. (2009) for earlier examples of New Keynesian open economies with staggered nominal wage setting.
} 
where $\Upsilon \equiv 1 /\left((1-v)^{(1-v)} v^{v}\right)$. $C_{H, t}$ is an index of domestic goods consumption given by $C_{H, t} \equiv\left(\int_{0}^{1} C_{H, t}(i)^{\frac{\epsilon_{p}-1}{\epsilon_{p}}} d i\right)^{\frac{\epsilon_{p}}{\epsilon_{p}-1}}$ where $i \in[0,1]$ denotes the good variety. ${ }^{5} C_{F, t}$ is the quantity consumed of a composite foreign good. Parameter $\epsilon_{p}>1$ denotes the elasticity of substitution between varieties produced domestically. Parameter $v \in[0,1]$ can be interpreted as a measure of openness. ${ }^{6}$

The $(\log )$ preference shifter, $z_{t} \equiv \log Z_{t}$, is assumed to follow an exogenous $A R(1)$ process:

$$
z_{t}=\rho_{z} z_{t-1}+\varepsilon_{t}^{z}
$$

Note that by affecting the marginal rate of substitution between consumption at different times, shocks to $z_{t}$ will change the demand for consumption goods, given the interest rate. Henceforth we refer to $z$ shocks as demand shocks.

The period budget constraint for the typical household is given by

$$
\int_{0}^{1} P_{H, t}(i) C_{H, t}(i) d i+P_{F, t} C_{F, t}+E_{t}\left\{Q_{t, t+1} D_{t+1}\right\} \leq D_{t}+\int_{0}^{1} W_{t}(j) \mathcal{N}_{t}(j) d j-T_{t}
$$

for $t=0,1,2, \ldots$, where $P_{H, t}(i)$ is the price of domestic variety $i . P_{F, t}$ is the price of the imported good, expressed in domestic currency. $D_{t+1}$ is the nominal payoff in period $t+1$ of the portfolio held at the end of period $t$ (which may include shares in domestic firms), $W_{t}(j)$ is the nominal wage for type $j$ labor. $T_{t}$ denotes lump-sum taxes. The previous variables are all expressed in units of domestic currency. $Q_{t, t+1} \equiv \beta\left(C_{t} / C_{t+1}\right)\left(P_{t} / P_{t+1}\right)$ is the relevant stochastic discount factor for one-period ahead nominal payoffs.

We assume that the law of one price holds. This implies that the price (in domestic currency) of imported goods is given by:

$$
P_{F, t}=\mathcal{E}_{t} P_{t}^{*}
$$

where $\mathcal{E}_{t}$ is the nominal exchange rate (the price of foreign currency in terms of domestic currency) and $P_{t}^{*}$ is the foreign price level (expressed in foreign currency). With little loss of generality, the latter is henceforth assumed to be constant and normalized to unity, i.e., $P_{t}^{*}=1$, for all $t$.

Workers specialized in each occupation (or a union representing them) set the corresponding nominal wage, subject to an isoelastic demand function for their services (derived below). Each period only a fraction $1-\theta_{w}$ of labor types, drawn randomly from the corresponding population, have their nominal wage reset. This is done in a way consistent with household utility maximization, while taking the average wage, the price level and

\footnotetext{
${ }^{5}$ As discussed below, domestic firms produce a continuum of differentiated goods, indexed by $i \in[0,1]$.

${ }^{6}$ Equivalently, and under the assumption that the domestic economy is infinitesimally small, $1-v$ can be interpreted as a measure of home bias. See Galí and Monacelli (2005) for a discussion.
} 
other aggregate variables as given. The remaining fraction $\theta_{w}$ of labor types keep their nominal wage unchanged. Parameter $\theta_{w} \in[0,1]$ can be thus seen as an index of nominal wage rigidities. Much of the analysis below explores the consequences of changes in that parameter.

\section{$1.2 \quad$ Firms}

A continuum of firms, indexed by $i \in[0,1]$, are assumed to operate in the home economy. A typical domestic firm produces a differentiated good using the technology

$$
Y_{t}(i)=A_{t} N_{t}(i)^{1-\alpha}
$$

where $Y_{t}(i)$ is output and $N_{t}(i) \equiv\left(\int_{0}^{1} N_{t}(i, j)^{\frac{\epsilon_{w}-1}{\epsilon_{w}}} d j\right)^{\frac{\epsilon_{w}}{\epsilon_{w}-1}}$ is a CES function of the quantities $N_{t}(i, j)$ of the different types of labor services $j \in[0,1]$ employed. Parameter $\epsilon_{w}>1$ denotes the elasticity of substitution between those labor services. $A_{t}$ is a stochastic technology parameter, common to all firms. Its $\log a r i t h m, ~ a_{t} \equiv \log A_{t}$, follows an exogenous $A R(1)$ process:

$$
a_{t}=\rho_{a} a_{t-1}+\varepsilon_{t}^{a}
$$

Employment is subject to a proportional payroll tax $\tau_{t}$, common to all labor types, so that the effective cost of type $j$ labor service is $W_{t}(j)\left(1+\tau_{t}\right) .^{7}$

Each period, a subset of firms of measure $1-\theta_{p}$, drawn randomly from the population, reoptimize the price of their good, subject to a sequence of isoelastic demand schedules for the latter. The remaining fraction $\theta_{p}$ keep their price unchanged. Parameter $\theta_{p} \in[0,1]$ can thus be interpreted as an index of price rigidities. Prices are set in domestic currency and are the same for both the domestic and export markets, i.e., the law of one price also holds for exports. All firms meet the demand for their respective goods at the posted prices. ${ }^{8}$

As in Galí and Monacelli (2005), we assume in our baseline model that households have access to a complete set of state-contingent securities, traded internationally. As shown in Appendix A, that assumption implies the following relationship between domestic and world consumption:

$$
C_{t}=C_{t}^{*} \mathcal{Q}_{t}\left(\frac{Z_{t}}{Z_{t}^{*}}\right)
$$

where $\mathcal{Q}_{t} \equiv \frac{\mathcal{E}_{t} P_{t}^{*}}{P_{t}}$ is the real exchange rate, $C_{t}^{*}$ is (per capita) world consumption and $Z_{t}^{*}$ is a discount factor shock in the rest of the world.

\footnotetext{
${ }^{7}$ Note that a negative value for $\tau_{t}$ should be interpreted as an employment subsidy.

${ }^{8}$ Following convention, we assume that average markups are sufficiently large and shocks sufficiently small that the probability that the posted price falls below the marginal cost is negligible.
} 


\subsection{Demand for Exports and Global Shocks}

We assume that the demand for exports of domestic good $i$ is given by:

$$
X_{t}(i)=\left(\frac{P_{H, t}(i)}{P_{H, t}}\right)^{-\epsilon_{p}} X_{t}
$$

for $i \in[0,1]$, where $P_{H, t} \equiv\left(\int_{0}^{1} P_{H, t}(i)^{1-\epsilon_{p}} d i\right)^{\frac{1}{1-\epsilon_{p}}}$ is the domestic price index and $X_{t}$ is an aggregate export index. The latter is assumed to be given by

$$
X_{t}=v \mathcal{S}_{t} Y_{t}^{*}
$$

where $Y_{t}^{*}$ is world output (expressed in per capita terms) and $\mathcal{S}_{t} \equiv P_{F, t} / P_{H, t}$ denotes the terms of trade. In equilibrium world output, $Y_{t}^{*}$, equals world consumption, $C_{t}^{*}$. Below we consider a symmetric steady state with $\mathcal{S}=1$ and $C=C^{*}=Y^{*}{ }^{9}$ In that case, $X=v Y^{*}$ and $C_{F}=v C$, implying a balanced trade, as well as $Y=C$, in that steady state.

We consider two types of global shocks that affect the home economy, and which we refer to as export shocks and world interest rate shocks, respectively. Export shocks shift the export function (5), leaving the world real interest rate unchanged. World interest rate shocks, by contrast, change the latter variable while leaving global output unchanged (thus influencing exports only through an eventual endogenous response of the terms of trade). Though both world output and the world interest rate are themselves endogenous variables and hence likely to be correlated, here we seek to understand their respective effects on the home economy by considering them in isolation. With that goal in mind, we introduce global shocks in our model as follows. We assume that the discount factor shifter for foreign households is given by

$$
Z_{t}^{*}=Z_{1, t}^{*} Z_{2, t}^{*}
$$

where $z_{1, t} \equiv \log Z_{1, t}$ and $z_{2, t} \equiv \log Z_{2, t}$ follow independent, exogenous $A R(1)$ processes:

$$
z_{i, t}=\rho_{i}^{*} z_{i, t-1}+\varepsilon_{i, t}^{*}
$$

for $i=1,2$. Exogenous shocks $Z_{1, t}^{*}$ and $Z_{2, t}^{*}$ are defined by the differential monetary policy responses they elicit from the (foreign) central bank. Thus, we assume that the world real interest rate remains unchanged in response to $Z_{1, t}^{*}$ shocks. By contrast, the foreign central bank is assumed to respond to $Z_{2, t}^{*}$ by adjusting the real interest rate in order to keep $Y_{t}^{*}$ unchanged. Under the assumption that foreign households have an Euler equation analogous to that of domestic households, that is,

\footnotetext{
${ }^{9}$ The equality among domestic and world steady state quantities should be understood as referring to per capita variables.
} 


$$
1=\beta\left(1+i_{t}^{*}\right) E_{t}\left\{\left(\frac{Y_{t}^{*}}{Y_{t+1}^{*}}\right)\left(\frac{Z_{t+1}^{*}}{Z_{t}^{*}}\right)\right\}
$$

it follows from the assumptions above, and the global market clearing condition $C_{t}^{*}=Y_{t}^{*}$, that

$$
Y_{t}^{*}=Z_{1, t}^{*}
$$

which implies that the risk sharing condition can be written as:

$$
C_{t}=\mathcal{Q}_{t} \frac{Z_{t}}{Z_{2, t}^{*}}
$$

The behavior of the world interest rate implied by the assumptions above is given by: ${ }^{10}$

$$
i_{t}^{*}=\rho+\left(1-\rho_{2}^{*}\right) z_{2, t}^{*}
$$

Thus, $z_{1, t}$ shocks have an effect on global output, shifting the demand for home exports (5). By contrast, $z_{2, t}$ alter the world real interest rate and shift the risk sharing condition (8); they only affect aggregate exports through their possible impact on the real exchange rate. ${ }^{11}$ This justifies our labeling of those shocks as export and world interest rate shocks, respectively.

\subsection{Monetary Regimes}

In the present section, we analyze the equilibrium behavior of the small open economy under two monetary policy regimes. Under the first regime, which we refer to as inflation targeting, the central bank focuses on stabilizing domestic inflation, $\pi_{H, t} \equiv p_{H, t}-p_{H, t-1}$, while letting the exchange rate fluctuate freely. Formally, we assume

$$
\pi_{H, t}=0
$$

for all $t$.

Under the second monetary regime, the home economy is assumed to be part of a world currency union. Alternatively (and equivalently for our purposes) it is assumed to peg the exchange rate indefinitely (and credibly) to the world currency. In either case, and letting $e_{t} \equiv \log \mathcal{E}_{t}$ denote the (log) nominal exchange rate, we assume without loss of generality:

$$
e_{t}=0
$$

\footnotetext{
${ }^{10}$ Note that this should be viewed as an equilibrium condition, not as an interest rate rule. The latter should be designed in order to guarantee not only consistency with the assumed behavior but also uniqueness of the equilibrium.

${ }^{11}$ Alternatively, $z_{2, t}$ shocks can also be reinterpreted directly as deviations from the optimal risk sharing condition resulting from the lack of complete markets.
} 
for all $t$. Note that under this second regime the domestic nominal interest rate will move one-for-one with the world interest rate, independently of domestic economic conditions.

The previous two regimes are, admittedly, extreme ones, though they have the virtue of allowing us to make our point in a simple and transparent way. In the robustness section below we extend our analysis to the intermediate case of a managed exchange rate regime, using a stylized parametric interest rate rule that allows for different degrees of central bank's concern for exchange rate stability.

\subsection{Equilibrium}

In Appendix A we derive the (standard) optimality conditions for the problem facing households and firms. Combined with the market clearing conditions and after loglinearization around the zero inflation steady state, they can be used to determine the set of conditions characterizing the equilibrium of the small open economy. That equilibrium can be represented by means of the following system of difference equations (with lower case letters denoting the natural logarithms of the original variables and with constants ignored):

Aggregate demand block:

$$
\begin{gathered}
y_{t}=(1-v) c_{t}+v(2-v) s_{t}+v z_{1, t}^{*} \\
c_{t}=(1-v) s_{t}+z_{t}-z_{2, t}^{*} \\
c_{t}=E_{t}\left\{c_{t+1}\right\}-\left(i_{t}-E_{t}\left\{\pi_{t+1}\right\}\right)+\left(1-\rho_{z}\right) z_{t} \\
s_{t} \equiv e_{t}-p_{H, t} \\
n_{t}=\frac{1}{1-\alpha}\left(y_{t}-a_{t}\right)
\end{gathered}
$$

Aggregate supply block:

$$
\begin{gathered}
\pi_{H, t}^{p}=\beta E_{t}\left\{\pi_{H, t+1}^{p}\right\}+\frac{\lambda_{p} \alpha}{1-\alpha} \widetilde{y}_{t}+\lambda_{p} \widetilde{\omega}_{t}+\lambda_{p} v \widetilde{s}_{t}+\lambda_{p} \tau_{t} \\
\pi_{H, t}^{p} \equiv p_{H, t}-p_{H, t-1} \\
\pi_{t}^{p} \equiv p_{t}-p_{t-1} \\
p_{t}=p_{H, t}+v s_{t} \\
\pi_{t}^{w}=\beta E_{t}\left\{\pi_{t+1}^{w}\right\}+\frac{\lambda_{w} \varphi}{1-\alpha} \widetilde{y}_{t}+\lambda_{w} \widetilde{c}_{t}-\lambda_{w} \widetilde{\omega}_{t} \\
\pi_{w, t}^{w} \equiv w_{t}-w_{t-1} \\
\omega_{t} \equiv w_{t}-p_{t}
\end{gathered}
$$


where variables with a " " denote deviations from their natural (i.e., flexible price and wage) equilibrium counterparts (e.g., $\widetilde{y}_{t} \equiv y_{t}-y_{t}^{n}$ denotes the output gap, with $y_{t}^{n}$ being the natural level of output).

The aggregate demand block includes equation (10) determining output as a function of aggregate demand, which in turn is expressed as a function of consumption $c_{t}$ and the terms of trade $s_{t}$ (defined in (13)). Consumption evolves according to Euler equation (12), and thus responds to changes in the domestic real rate and the preference shifter. In addition, domestic consumption satisfies the risk sharing condition (11). ${ }^{12}$ Equation (14) determines employment as a function of aggregate output, given technology.

The aggregate supply block consists of two equations, (15) and (17), describing the evolution of aggregate (domestic) price and wage inflation (defined, respectively, by (16) and (18)), as a function of the output, consumption and real wage gaps (as well as the payroll tax in the case of price inflation). Finally, (19) defines the real (consumption) wage, as a function of the nominal wage, the domestic price and the terms of trade. ${ }^{13}$

As derived in Appendix A, natural employment, which we denote by $n_{t}^{n}$ is given by (ignoring a constant term)

$$
n_{t}^{n}=\frac{v}{1+\varphi}\left(z_{1, t}^{*}+z_{2, t}^{*}-z_{t}\right)-\frac{1}{1+\varphi} \tau_{t}
$$

Note that under our assumptions on technology and preferences, and in the absence of variations in the employment subsidy, natural employment would be constant in a closed economy (i.e., under $v=0$ ).

The previous expression can be combined with other equilibrium conditions to derive the natural values of the remaining variables. Thus, and ignoring constants,

$$
\begin{gathered}
y_{t}^{n}=a_{t}+(1-\alpha) n_{t}^{n} \\
s_{t}^{n}=a_{t}-z_{t}+z_{2, t}^{*}-\tau_{t}-(\alpha+\varphi) n_{t}^{n} \\
c_{t}^{n}=z_{t}+(1-v) s_{t}^{n}-z_{2, t}^{*} \\
\omega_{t}^{n}=a_{t}-\alpha n_{t}^{n}-\tau_{t}-v s_{t}^{n}
\end{gathered}
$$

\footnotetext{
${ }^{12}$ The intertemporal optimality conditions of the domestic and foreign consumers can be combined to yield, as a first order approximation, the interest parity condition

$$
i_{t}-i_{t}^{*}=E_{t}\left\{\Delta e_{t+1}\right\}
$$

We do not list that condition separately since it can be obtained by combining (9), (11) and (12).

${ }^{13}$ Note that $p_{H, t}+\nu s_{t}=p_{t}$ corresponds to the (log) CPI.
} 


\subsection{Calibration}

Table 1 lists the baseline settings for the model parameters, which we use in the simulations below. The top panel contains the parameters relevant to the baseline model described above. Parameters in the bottom panel are specific to the more general model used in Section 5, and are discussed therein.

Parameters $\epsilon_{p}$ is set to 3.8. That value is associated with a steady state price markup of 35 percent, and is consistent with the evidence used in the calibration of the ECB's New Area Wide Model (NAWM) of Christoffel et al. (2008). Given that setting, a value of 0.26 for parameter $\alpha$ is consistent with the observed 0.55 average labor income share across Greece, Italy, Portugal, and Spain (GIPS, henceforth) over the 1999-2014 period. ${ }^{14}$

Parameter $\epsilon_{w}$ is set to 4.3, again following Christoffel et al. (2008). Given that setting for $\epsilon_{w}$, and using the approach developed in Galí (2011), a value of $\varphi$ equal to 2.2 can be shown to be consistent with a steady state unemployment rate of 11.8 percent, the average unemployment rate across the GIPS over the 1999-2014 period. ${ }^{15}$

Our baseline setting for the Calvo price parameter is $\theta_{p}=0.8$, which implies an average duration of individual prices of five quarters. That setting strikes a balance between estimates for the euro area based on micro data (see, e.g. Álvarez et al. (2006)) and those that match the macro data (see, e.g., Galí, López-Salido and Gertler (2001, 2003), Christoffel et al. (2008), Burriel et al. (2009)). As to the Calvo wage parameter, both the micro and macro evidence suggest that a baseline setting for $\theta_{w}$ of 0.8 is also a reasonable one for euro area countries (see, e.g., Christoffel et al. (2008), ECB (2009)).

The openness parameter, $v$, is set to 0.3 (implying a steady state import share of that value). This is consistent with measures of openness (average export and import shares) in the GIPS countries. Finally, we set $\beta=0.99$, as is common practice in the business cycle literature.

In the robustness section we introduce additional parameters and their calibrated values.

${ }^{14}$ Note that in the steady state the following relation holds:

$$
\frac{W N}{P Y}=(1-\alpha)\left(1-\frac{1}{\epsilon_{p}}\right)
$$

${ }^{15}$ Galí (2011) shows that the $\varphi, \epsilon_{w}$ and the steady state unemployment rate $u$ are related according to equation:

$$
\varphi u=\log \frac{\epsilon_{w}}{\epsilon_{w}-1}
$$

Interestingly, the resulting setting for $\varphi$ is nearly identical to the calibrated value in the NAWM of Christoffel et al. (2008). 


\section{The Effectiveness of Labor Cost Reductions}

The extent to which wage flexibility may play a stabilizing role depends on the influence that wages (or other labor cost components) may have on employment itself. In this section we seek to dissect the mechanism through which that influence manifests itself in our model economy, as well as its dependence on the monetary policy regime.

As argued in Galí (2013), the mechanism through which adjustments in wages end up affecting employment in the New Keynesian model is very different from that in a classical economy. In the latter, a change in the real wage directly affects the quantity of labor demanded by firms, which is determined by the equality between the marginal product of labor and the wage. By way of contrast, in a Keynesian environment the amount of labor hired is determined, in the short run and for a given technology, by the quantity of output that firms want to produce, which in turn is determined by aggregate demand. Thus, in a closed economy, a change in wages ends up affecting employment through its (sequential) impact on marginal cost, inflation and -through the monetary policy rule-nominal and real interest rates and, hence, consumption and other interest rate-sensitive components of aggregate demand (including net exports, through the effects induced by the possible response of the nominal exchange rate). Thus, the strength of the central bank's response to variations in inflation is a key factor in determining the response of employment to a change in wages (or other labor costs). This is what we refer to as the "endogenous policy channel". Clearly, the importance of that channel depends on the degree to which monetary policy is constrained in its response to inflation. In particular, if the economy belongs to a currency union and is small enough not to elicit a response by the common central bank, the endogenous policy channel will be completely muted.

In addition to the endogenous policy channel just described, there is a second channel through which a reduction in labor costs may affect employment in the open economy: the resulting drop in marginal costs and prices make domestic firms more competitive relative to their foreign counterparts, leading to an increase in the demand for their goods, even if the nominal exchange rate remains unaltered (as will be the case in a currency union). We refer to this mechanism as the "competitiveness channel".

In order to illustrate the role played by the policy regime in determining the effects of changes in labor costs, we simulate the response of employment to a one-off, exogenous reduction in the payroll tax under two alternative policy regimes: inflation targeting and a currency union (or a hard peg). ${ }^{16}$

A reduction in the payroll tax provides a good example of the type of interventions that are often advocated as a way to stimulate economic activity in high unemployment, debt-ridden countries. That advice is especially targeted to those countries that can no

\footnotetext{
${ }^{16}$ To be clear: we do not think that exogenous variations in payroll taxes or employment subsidies are an important source of fluctuations in actual economies. But a change in the payroll tax provides a clean experiment to examine the impact of changes in labor costs on employment.
} 
longer rely on a currency devaluation to regain competitiveness, due to their membership in a currency union.

More specifically, we assume the payroll tax is lowered by $\widehat{\tau}_{0}<0$ in period zero, and subsequently follows the path:

$$
\widehat{\tau}_{t}=\rho_{\tau}^{t} \widehat{\tau}_{0}<0
$$

Figure 1a displays the response of employment, the nominal and real interest rates, and the terms of trade to a one percent (impact) reduction in the payroll tax in the home economy, under the assumption that $\rho_{\tau}=0.9$. The lines with circles display the responses under an inflation targeting regime, while the lines with diamonds show the responses under a currency union. Our findings are clear: The effectiveness of the payroll tax cut as a means to stimulate employment is much smaller under a currency union, compared to the case of an autonomous monetary policy focused on price stability.

To understand the previous result, note that equation (10) implies that the response of output (and, hence, of employment, given an unchanged technology) is directly related to the responses of consumption and the terms of trade. To understand the consumption response, we can combine equations (11) and (12) (setting all other shocks to zero) to obtain:

$$
c_{t}=-(1-v) \sum_{k=0}^{\infty} E_{t}\left\{r_{t+k}\right\}+\lim _{k \rightarrow \infty} E_{t}\left\{c_{t+k}\right\}
$$

where $r_{t} \equiv i_{t}-E_{t}\left\{\pi_{H, t+1}\right\}$ is the real interest rate, measured in terms of domestic goods, and where $\lim _{k \rightarrow \infty} E_{t}\left\{c_{t+k}\right\}=0$ (in deviation from steady state) in the case of a transitory tax cut, as assumed in Figure 1a. Thus, the response of consumption to a payroll tax cut is inversely related to the sum of current and expected future real rates. It is easy to show that a similar result holds for the terms of trade: by combining (11) and (12), one can derive a "real" version of the uncovered interest parity condition (assuming an unchanged foreign real rate):

$$
s_{t}=-r_{t}+E_{t}\left\{s_{t+1}\right\}
$$

which in turn can be solved forward to yield

$$
s_{t}=-\sum_{k=0}^{\infty} E_{t}\left\{r_{t+k}\right\}+\lim _{k \rightarrow \infty} E_{t}\left\{s_{t+k}\right\}
$$

where, again, $\lim _{k \rightarrow \infty} E_{t}\left\{s_{t+k}\right\}=0$ in response to a transitory tax cut. Thus, it follows that the effect of a payroll tax cut on employment will depend critically on the dynamic response of the real interest rate, which in the presence of nominal rigidities of the sort assumed here is strongly shaped by the monetary regime in place.

More specifically, the impact on employment of a payroll tax change is given, up to a 
proportionality factor, by:

$$
\begin{aligned}
\partial n_{t} & \propto-\partial \sum_{k=0}^{\infty} E_{t}\left\{r_{t+k}\right\} \\
& =-\partial p_{H, t}-\partial \sum_{k=0}^{\infty} E_{t}\left\{i_{t+k}\right\}+\partial \lim _{k \rightarrow \infty} E_{t}\left\{p_{H, t+k}\right\}
\end{aligned}
$$

As shown in Figure 1a, under a currency union the nominal rate remains unchanged in response to the the payroll tax cut, despite the inflation decline (not shown) in the home economy. In other words, the "endogenous policy channel" is muted. Furthermore, in the case of a transitory shock, the domestic price level eventually returns to its initial value, since the terms of trade do not change in the long run. Accordingly, the "long real rate" will move one-for-one with the initial change in the domestic price level, i.e., $\partial \sum_{k=0}^{\infty} E_{t}\left\{r_{t+k}\right\}=\partial p_{H, t}$. Thus, in this case the employment stimulus relies exclusively on the "competitiveness channel," i.e., on the extent of the short run drop in domestic prices. Note that the latter reduces the long real rate, triggering a small increase in both consumption (not shown) and the terms of trade, and accounting for the positive (albeit small) employment response. Note also that the decrease in the long real rate coexists with a short run increase in the short-term real rate due to the initial decline in expected inflation, as is apparent in Figure 1a.

By contrast, and as illustrated in Figure 1a, under flexible exchange rates and an inflation targeting regime the reduction in the payroll tax triggers a large and persistent decline in nominal and real interest rates, a response that is required in order to stabilize domestic prices. The resulting large rise of consumption is complemented by a commensurate depreciation of the terms of trade, with both contributing to the large increase in employment. Note that in that case $n_{t} \propto-\partial \sum_{k=0}^{\infty} E_{t}\left\{i_{t+k}\right\}$, i.e., the employment stimulus fully hinges on the "endogenous policy channel".

Things are not too different if we consider instead a permanent payroll tax cut, an intervention which likely matches more closely the policies often advocated for countries experiencing high unemployment rates. Figure $1 \mathrm{~b}$ displays the dynamic responses for that case, corresponding to $\rho_{\tau}=1$. Note that in this case both employment and the terms of trade are permanently raised by the tax cut, with the size of the long run effect being independent of the monetary regime. That similarity notwithstanding, the large differences in the short run effects closely mirror those observed under a transitory (though persistent) payroll tax cut discussed above.

To summarize: in this section we have shown that, in a small open economy, the effects on employment of exogenous changes in labor costs are strongly mediated by the response of monetary policy and hence by the monetary policy regime in place. When the exchange rate is fixed, as in a currency union, supply side interventions aimed at stimulating employment through a reduction in labor costs appear to be less effective 
than under an independent, price stability-oriented monetary policy. Thus, and contrary to conventional wisdom, labor cost reductions appear to be particularly ineffective in a small economy that is part of a currency union.

The previous finding suggests that when an economy belongs to a currency union (or has adopted a hard peg), an increase in wage flexibility, with its consequent greater sensitivity of labor costs to cyclical conditions, may not bring the employment stability benefits that are generally expected from it. An analysis of those benefits is the focus of the next section.

\section{Wage Flexibility, Exchange Rate Policy and Wel- fare}

The previous section has focused on the role played by a small open economy's monetary policy regime in determining the employment effects of a one-off, exogenous change in labor costs (in the form of a payroll tax cut). In actual economies, however, exogenous shocks to wages or other labor cost components are likely to be rare events. Instead, labor costs are better viewed as endogenous, with wages adjusting to changes in economic conditions resulting from a variety of demand and/or supply shocks. Needless to say, that adjustment may be faster or slower depending on the degree of wage flexibility.

As argued in the introduction, the degree of wage flexibility, i.e., the sensitivity of the average wage to changes in economic conditions, is generally viewed as a key determinant of employment stability. Thus, and in the face of an adverse shock, a reduction in the average wage is likely to insulate, at least partly, the impact on employment of that shock. But the findings in the previous section suggest that the monetary regime adopted by a small open economy will be an important determinant of the extent to which endogenous wage adjustments may be effective in stabilizing employment fluctuations. In particular, in the case of a small economy belonging to a currency union that effectiveness is likely to be limited, due to the lack of an "endogenous policy channel." The previous observation, combined with the fact that - as is the case in our model economy- (i) fluctuations in wage and price inflation are costly in their own right and (ii) the size of such fluctuations is likely to increase with wage flexibility, raises the possibility that an increase in wage flexibility may be counterproductive from a welfare viewpoint, its stabilizing benefits being too small to offset its harmful side effects.

In the present section we analyze formally the welfare gains from increased wage flexibility in a small open economy. In particular, we seek to find out whether conditions exist under which, contrary to conventional wisdom, "improvements" in wage flexibility may be welfare-reducing.

In the next subsection we restrict our analysis to the baseline model specification introduced above. Two assumptions of that model-namely, log utility of consumption and 
a unit elasticity of substitution between domestic and foreign goods-allow us to derive a simple second order approximation to the welfare losses experienced by the representative household in the small open economy. Robustness of our findings to departures from that baseline specification are discussed in section 4 .

\subsection{Wage Flexibility and Welfare in a Currency Union}

Under the assumption of an efficient steady state, the average period utility losses of the small open economy's representative household are given, up to a second order approximation, by the following linear combination of the variances of the employment gap, price inflation and wage inflation: ${ }^{17}$

$$
\mathbb{L} \sim\left(\frac{1-v}{2}\right)\left[(1+\varphi) \operatorname{var}\left(\widetilde{n}_{t}\right)+\left(\frac{\epsilon_{p}}{\lambda_{p}(1-\alpha)}\right) \operatorname{var}\left(\pi_{t}^{p}\right)+\left(\frac{\epsilon_{w}}{\lambda_{w}}\right) \operatorname{var}\left(\pi_{t}^{w}\right)\right]
$$

where $\widetilde{n}_{t} \equiv n_{t}-n_{t}^{e}$ is the log deviation between employment and its efficient level, $n_{t}^{e}=$ $\frac{v}{1+\varphi}\left(z_{1, t}^{*}+z_{2, t}^{*}-z_{t}\right)$.

Figure 2 displays the average welfare loss for a small open economy in a currency union as a function of the degree of wage stickiness, $\theta_{w}$, and conditional on each of the four exogenous driving forces introduced above, namely, two domestic shocks (technology and demand) and two external shocks (export and world interest rate). All parameters other than $\theta_{w}$ are set at their baseline values. In each case the welfare losses are expressed as a ratio to those under the baseline setting $\theta_{w}=0.8$.

As Figure 2 makes clear, the relationship between the welfare loss and the degree of wage rigidity is non-monotonic, independently of the driving force. Starting from a value of $\theta_{w}$ close to unity, a reduction in that parameter (i.e., making wages "more flexible") always raises welfare losses. On the other hand, if wages are sufficiently flexible to begin with (i.e., $\theta_{w}$ is sufficiently low), a further increase in wage flexibility always leads to a decline in welfare losses. Thus, an increase in wage flexibility may raise or lower welfare, depending on the initial degree of wage rigidities. Note also that the shape of the welfare loss function varies considerably with the type of shock. Thus, the maximum is attained for very different values of $\theta_{w}$ and the function displays significantly different sensitivities to changes in that parameter, depending on the driving shock. In particular, the loss function appears to be nearly monotonic in the case of export shocks.

In order to understand the factors behind such patterns, Figure 3 displays the welfare losses associated with demand shocks (line with circles), together with the three compo-

\footnotetext{
${ }^{17}$ See Galí and Monacelli (2005) for a derivation of the welfare loss function of the small open economy with sticky prices and flexible wages. The extension to the case of sticky wages is straightforward. See, e.g., chapter 6 in Galí (2015). As in our earlier paper we implicitly assume the existence of a subsidy that makes the steady state efficient from the viewpoint of the small open economy. The robustness section below relaxes that assumption.
} 
nents of the welfare loss function, each being associated with one of the three terms in (20). Similar qualitative results hold for the remaining shocks (not shown).

With regard to the first component, associated with employment gap fluctuations (represented with the line with diamonds), we see that an increase in wage flexibility always reduces the contribution of that component to overall welfare losses, though the size of that reduction is relatively slow, due to the limited influence of wage adjustments on employment in an economy that belongs to a currency union or has adopted a hard peg, as discussed above. Turning to the second component (line with squares), we observe that an increase in wage flexibility always raises the volatility of price inflation, and thus the contribution of the latter to welfare losses. Note that these first two components of welfare losses largely compensate each other. Finally, note that the wage inflation component of welfare losses (line with crosses) displays the kind of non-monotonicity displayed by the overall loss, so its contribution is particularly important in order to account for the finding in Figure 3. The explanation for that non-monotonicity is straightforward. On the one hand the variance of wage inflation increases monotonically as wages become more flexible. This effect, which tends to raise welfare losses, is dominant when $\theta_{w}$ is relatively large thus accounting for the negative relationship between welfare losses and $\theta_{w}$ over the upper range of the latter. On the other hand, the weight associated with wage inflation volatility in the loss function, $\epsilon_{w} / \lambda_{w}$, shrinks rapidly as wages become more flexible, accounting for the positive relation between welfare losses and $\theta_{w}$ when the latter parameter is below a certain level. $^{18}$

Figure 4 compares the welfare effects of changes in wage flexibility in a currency union to the case of an inflation targeting regime. ${ }^{19}$ The differences across the two regimes, both qualitative and quantitative, are clear. In particular, and as Figure 4 makes clear, under inflation targeting an increase in wage flexibility is always welfare improving, independently of the initial degree of rigidities and the source of fluctuations. Furthermore, the sensitivity of welfare losses to changes in the wage rigidity parameter appears to be much greater under inflation targeting. In other words, even when an increase in wage flexibility is welfare improving in a currency union, the implied change in welfare is small relative to that observed under inflation targeting.

The analysis above has examined the impact of changes in the degree of wage rigidities while keeping the price rigidity parameter, $\theta_{p}$, unchanged at its baseline value of 0.8 . To what extent are the welfare effects of a change in the degree of wage rigidities altered if that change is accompanied by one in the same direction in the degree of price rigidities? Figure 5 seeks to shed some light on that question by plotting, for each driving force, the welfare losses under a currency union, as a function of the degree of overall nominal rigidities, as captured by variation in a common value for $\theta_{w}$ and $\theta_{p}$ (denoted by $\theta$ ) in the

\footnotetext{
${ }^{18}$ Note that $\lim _{\theta_{w} \rightarrow \infty} \lambda_{w}=+\infty$

${ }^{19}$ In both cases the welfare losses are, again, expressed relative to those under the baseline setting $\theta_{w}=0.8$.
} 
Figure. Two findings are worth stressing. First, the non-monotonicity that characterized the welfare loss function under a currency union when only the wage rigidity parameter was adjusted (Figure 2) is preserved here, when both price and wage rigidities are varied simultaneously. Thus one can still argue that an increase in the flexibility of wages and prices jointly may be welfare reducing under a currency union, when rigidities are strong to begin with, and in contrast with conventional wisdom. On the other hand, it is clear that for most shocks the range of $\theta$ values for which that finding obtains is smaller, with welfare improving rapidly and substantially as wage and price rigidities are further reduced, once a certain flexibility threshold is attained. The previous analysis points to the desirability of simultaneous "improvements" in goods and labor markets, aimed at making both prices and wages more responsive to economic conditions.

\section{Gains from Wage Flexibility in a Medium-Scale DSGE Model}

In this section we assess the robustness of some of our key findings using a quantitative DSGE model, which extends the baseline model employed so far along several dimensions. We briefly list some of the additional features next. First, we assume more general preferences, allowing for habit formation. Second, we introduce endogenous capital accumulation (subject to adjustment costs). Third, we allow for incomplete exchange rate pass-through, resulting from the combined effect of nominal price stickiness in import prices (as in Monacelli (2005) and Adolfson et al. (2007)) and local distribution costs (as in Burstein et al. (2007) and Corsetti and Dedola (2005)). More specifically, we assume that local labor is employed in the distribution of imported consumption goods. As a result, deviations from the law of one price in tradables are the result of both price and wage stickiness. Fourth, we assume (partial) indexation of wages and prices (both for domestic and imported goods). Fifth, we calibrate the exogenous stochastic processes using moments estimated from the data. Sixth, we assume a more general interest rate rule that parameterizes the central bank's relative weight on inflation and exchange rate stability. Finally, we allow for the possibility of uncorrected monopolistic distortions, and evaluate welfare losses around an inefficient steady state. Below we briefly sketch the new features of the DSGE model relative to the baseline model, and refer to Appendix B for further details. ${ }^{20}$

The aggregate consumption index is now defined by:

$$
C_{t} \equiv\left((1-v)^{\frac{1}{\eta}} C_{H, t}^{1-\frac{1}{\eta}}+v^{\frac{1}{\eta}} C_{F, t}^{1-\frac{1}{\eta}}\right)^{\frac{\eta}{\eta-1}}
$$

\footnotetext{
${ }^{20}$ Appendix B contains the details of the DSGE model with only traded goods. Appendix C extends the baseline DSGE model to a setting with traded and non-traded goods.
} 
where $C_{F, t}$ is a composite index of differentiated imported goods given by the CES function $C_{F, t} \equiv\left(\int_{0}^{1} C_{F, t}(i)^{\frac{\epsilon_{p}-1}{\epsilon_{p}}} d i\right)^{\frac{\epsilon_{p}}{\epsilon_{p}-1}}$ with $i \in[0,1]$, and where $\eta>0$ denotes the elasticity of substitution between the domestic and the imported consumption bundle.

Domestic goods are produced using a technology described by the production function:

$$
Y_{t}(i)=A_{t} N_{t}(i)^{1-\alpha} K_{t}^{\alpha}(i)
$$

Capital is accumulated by households and rented to firms. Capital accumulation of capital obeys the law of motion:

$$
K_{t+1}=(1-\delta) K_{t}+I_{t}\left[1-\frac{\omega_{k}}{2}\left(\frac{I_{t}}{I_{t-1}}-1\right)^{2}\right]
$$

where $K_{t}$ is the stock of capital at the beginning of period $t, I_{t}$ is investment in a final composite good (analogous to $(21)$ ), $\delta \in[0,1]$ is the rate of physical depreciation, and $\omega_{k} \geq 0$ is a parameter that scales the size of (quadratic) adjustment costs in investment.

Preferences of the representative household take the form:

$$
U\left(\widetilde{C}_{t},\left\{\mathcal{N}_{t}(j)\right\} ; Z_{t}\right)=\left(\log \widetilde{C}_{t}-\frac{1}{1+\varphi} \int_{0}^{1} \mathcal{N}_{t}(j)^{1+\varphi} d j\right) Z_{t}
$$

where $\widetilde{C}_{t}(j) \equiv C_{t}(j)-h C_{t-1}$ denotes habit-adjusted consumption, with $h \in[0,1]$.

Nominal stickiness in import prices and the presence of local distribution costs generate deviations from the law of one price (LOP). We define the LOP gap to be (under the assumption $\left.P_{F, t}^{*}=1\right)$ :

$$
\Phi_{F, t} \equiv \frac{\mathcal{E}_{t}}{P_{F, t}}
$$

Note that in the case of complete pass-through, $\Phi_{F, t}=1$ for all $t$. Letting the CPI be given by $P_{t} \equiv\left((1-v) P_{H, t}^{1-\eta}+v P_{F, t}^{1-\eta}\right)^{\frac{1}{1-\eta}}$, we can now express the real exchange rate as:

$$
\begin{aligned}
\mathcal{Q}_{t} & \equiv \frac{\mathcal{E}_{t}}{P_{t}} \\
& =\Phi_{F, t} \frac{\mathcal{S}_{t}}{q\left(\mathcal{S}_{t}\right)}
\end{aligned}
$$

where $q\left(\mathcal{S}_{t}\right) \equiv\left(1-v+v \mathcal{S}_{t}^{1-\eta}\right)^{\frac{1}{1-\eta}}$ is an increasing function of the terms of trade.

Each variety of imported goods is distributed to the final consumer by a local importer. Distributing $C_{F}$ units of import variety $f$ to the local consumer requires combining $M_{F, t}$, a homogeneous imported input, with local labor, according to the following constant return to scale production function: 


$$
C_{F, t}(f)=M_{F, t}(f)^{\alpha_{F}} N_{t}(f)^{1-\alpha_{F}}
$$

where $M_{F, t}(f)$ and $N_{t}(f)$ denote the quantity of imported input and local labor employed by importer $f$, and $\alpha_{F} \in[0,1]$.

Let $P_{F, t}^{*}$ be the "dock price" of the imported input (expressed in units of foreign currency), and let $P_{F, t}(f)$ be the "retail" price of the distributed variety $f$ (in terms of domestic currency). Assuming $P_{F, t}^{*}=1$, for all $t$, the cost minimization conditions imply the following expression for the importer's nominal marginal cost (common across local importers):

$$
\Psi_{F, t}=\Upsilon_{F} W_{t}^{1-\alpha_{F}} \mathcal{E}_{t}^{\alpha_{F}}
$$

where $\Upsilon_{F} \equiv\left(1-\alpha_{F}\right)^{-\left(1-\alpha_{F}\right)} \alpha_{F}^{-\alpha_{F}}$.

Each period, a local importer can change the retail price of the variety it distributes only with probability $1-\theta_{F}$. The newly set price in period $t$ by importer $f$, denoted by $\bar{P}_{F, t}(f)$, must solve: ${ }^{21}$

$$
\max _{\bar{P}_{F, t}(f)} E_{t} \sum_{k=0}^{\infty}\left(\beta \theta_{F}\right)^{k} U_{c, t+k}\left[\left(\bar{P}_{F, t}(f)-\Psi_{F, t+k}\right) C_{F, t+k}(f)\right]
$$

subject to (26) and to the demand function for variety $f$, which is given by

$$
C_{F, t+k}(f)=\left(\frac{\bar{P}_{F, t}(f)}{P_{F, t+k}}\right)^{-\epsilon_{p}} C_{F, t+k} .
$$

The aggregate export demand function is now assumed to be given by

$$
\begin{aligned}
X_{t} & =v\left(\frac{P_{H, t}}{\mathcal{E}_{t}}\right)^{-\eta} Y_{t}^{*} \\
& =v\left(\mathcal{S}_{t} \Phi_{F, t}\right)^{\eta} Y_{t}^{*}
\end{aligned}
$$

where the second equality makes use of (24).

The market clearing for each domestic variety $i$ is now given by

$$
Y_{t}(i)=\left(\frac{P_{H, t}(i)}{P_{H, t}}\right)^{-\epsilon_{p}}\left[(1-v) q\left(\mathcal{S}_{t}\right)\left(C_{t}+I_{t}\right)+v\left(\mathcal{S}_{t} \Phi_{F, t}\right)^{\eta} Y_{t}^{*}\right]
$$

Households and firms (both domestic producers and importers) not reoptimizing their wages or prices are assumed to adjust them mechanically according to the following indexation rules:

$$
W_{t}(j)=\Pi_{t-1}^{\chi_{w}} W_{t-1}(j)
$$

\footnotetext{
${ }^{21}$ For simplicity, we present here the optimal pricing problem under the assumption of no indexation. See Appendix B for the full specification.
} 


$$
\begin{aligned}
& P_{H, t}(i)=\prod_{H, t-1}^{\chi_{p}} P_{H, t-1}(i) \\
& P_{F, t}(f)=\prod_{F, t-1}^{\chi_{f}} P_{F, t-1}(f)
\end{aligned}
$$

where $\chi_{i} \in[0,1]$, for $i=w, p, f$.

We assume that monetary policy is described by an interest rate rule augmented with partial adjustment:

$$
i_{t}=\rho+\phi_{i} i_{t-1}+\left(1-\phi_{i}\right) i_{t}^{T}
$$

where the target interest rate is given by

$$
i_{t}^{T} \equiv \frac{1-\phi_{e}}{\phi_{e}} \pi_{H, t}+\frac{\phi_{e}}{1-\phi_{e}} e_{t}
$$

with $\phi_{e} \in[0,1]$, i.e., the central bank is assumed to respond to the nominal exchange rate in addition to domestic inflation. That specification allows us to capture the exchange rate stabilization motive that characterizes managed exchange rate regimes. Notice that the same specification nests the two polar monetary policy regimes considered in the baseline model: strict domestic inflation targeting $\left(\phi_{e} \rightarrow 0\right)$ and a currency union or a hard peg $\left(\phi_{e} \rightarrow 1\right)$. Values of $\phi_{e} \in(0,1)$ parameterize hybrid regimes of managed exchange rates. ${ }^{22}$

\subsection{Calibration}

The DSGE model requires the calibration of a few additional parameters, as summarized in the bottom panel of Table 1 and in Table 2. Next we summarize how we calibrated the additional parameters.

We set the habit formation and investment adjustment costs parameters to $h=0.564$ and $\omega_{k}=5.17$, respectively, in line with the estimated values reported in Christoffel et al. (2008). We set $\delta=0.025$, which corresponds to an annual depreciation rate of 10 percent. We calibrate the labor coefficient in the importers' production function to match the margin in the distribution sector. The estimates in Campa and Goldberg (2006) show that the distribution margin in the GIPS amounts, on average, to roughly 38 percent. ${ }^{23}$ In our setting, that margin is measured by $\left(1-\alpha_{F}\right)$, i.e., the elasticity of the (consumer-level) import price to the labor component in the importers' marginal cost. ${ }^{24}$ Based on the estimates from Christoffel et al. (2008) we set the Calvo index of (domestic

\footnotetext{
${ }^{22}$ Many regimes officially classified as floating rates, both in developed and especially developing countries, involve de facto an active degree of nominal exchange rate stabilization. See for instance Calvo and Reinhart (2002) and Reinhart (2000).

${ }^{23}$ See Campa and Goldberg (2006) Table 5.

${ }^{24}$ In the limit case of $\alpha_{F} \rightarrow 1$, the consumer-level price of the imported good would correspond to its "dock price", and therefore would not incorporate any distribution margin.
} 
currency) import price rigidity, $\theta_{F}$, to 0.528 , and the indexation parameters to $\chi_{p}=0.417$, $\chi_{f}=0.48$, and $\chi_{w}=0.635$.

We set $\phi_{e}=1$ (currency union) in our baseline interest rate rule calibration, though we report results for the full range of $\phi_{e}$ values later on, using a partial adjustment coefficient of $\phi_{i}=0.7$. Given the uncertainty in the literature about $\eta$, the trade elasticity of substitution, we do not take a specific stand on its value and report robustness exercises across three different values: $\eta \in\{0.5,1,2\}$. Note that $\eta=1$ corresponds to our baseline case. The values of all remaining parameters are as in the baseline model (see top panel of Table 1).

We next turn to the calibration of the exogenous driving processes. Using quarterly data over the sample 1999Q1-2014Q4, we approximate (log) total factor productivity as $a_{t}^{i}=y_{t}^{i}-0.74 n_{t}^{i}$, where $y_{t}^{i}$ and $n_{t}^{i}$ denote HP-filtered (log) output and (log) employment in country $i \in G I P S$. We then fit an $\operatorname{AR}(1)$ process for $a_{t}^{i}$ :

$$
a_{t}^{i}=\rho_{a}^{i} a_{t-1}^{i}+\varepsilon_{a, t}^{i}
$$

We set $\rho_{a}$ and $\sigma_{a}$ (the standard deviation of the innovation) to the average value of the estimated $\rho_{a}^{i}$ and $\sigma_{a}^{i}$ across $i \in G I P S$. The corresponding values are reported in Table 2 .

Given equation ( 7$)$ above, we calibrate parameters $\left(\rho_{1}^{*}, \sigma_{1}^{*}\right)$ describing the process for the foreign preference shock $\left\{z_{1, t}^{*}\right\}$ by estimating an AR(1) process for HP-filtered (log) euro area GDP using quarterly data from 1999Q1 to 2014 Q4.

Calibration of $\left\{z_{2, t}^{*}\right\}$ exploits the link between the latter and the foreign interest rate implied by equation (9) above. Together with our assumptions on the structure of foreign shocks and inflation implies

$$
i_{t}^{*}=\rho+\left(1-\rho_{2}^{*}\right) z_{2, t}^{*}
$$

Accordingly, we calibrate $\left(\rho_{2}^{*}, \sigma_{2}^{*}\right)$ by combining the previous equation with estimates of an $A R(1)$ process for the German three-month nominal rate (HP-detrended, 1999Q12014Q4, quarterly rate).

Finally, and conditional on the other shock processes being calibrated as above, we set the persistence and standard deviation of the $\mathrm{AR}(1)$ process for the domestic preference

shock $\left(\rho_{z}, \sigma_{z}\right)$, in order to (residually) fit the average persistence and volatility of the HP-filtered (log) GDP across the GIPS countries.

\subsection{Welfare}

For the DSGE model developed above an analytical expression for the welfare loss function is not readily available in closed form. We therefore evaluate welfare losses numerically. More specifically, we determine the fraction of consumption $\lambda_{u}$ that equates the unconditional expected utility along the equilibrium path to its value in the deterministic steady 
state. $^{25}$ Formally, $\lambda_{u}$ solves:

$$
E\left\{U\left(\widetilde{C}_{t}\left(1+\lambda_{u}\right),\left\{\mathcal{N}_{t}(j)\right\} ; Z_{t}\right)\right\}=U(C(1-h), N ; 1),
$$

where $E\{\cdot\}$ is the unconditional expectation operator, and the right hand side term measures utility at the deterministic steady state. In order to compute the left-hand side of (31) accurately, we evaluate $U(\cdot)$ up to second order. ${ }^{26}$

\subsection{Findings}

Our main findings on the welfare effects of wage rigidities based on the DSGE model described above are summarized in Figures 6 through 10. Figures $6 \mathrm{a}$ and $6 \mathrm{~b}$ describe, for the case of a currency union $\left(\phi_{e}=1\right)$, the effect on welfare losses of variations in the degree of wage rigidity, $\theta_{w}$, conditional on each shock (Figure 6a) and with all shocks simultaneously active (Figure 6b). In all cases, welfare losses are expressed as a ratio to its value under the baseline wage rigidity $\left(\theta_{w}=0.8\right)$. The price rigidity parameter is kept unchanged at its baseline setting of $\theta_{p}=0.8$. The main message of our above analysis based on the baseline model is largely confirmed in the context of the DSGE model: If monetary policy is constrained by an exchange rate peg, an increase in wage flexibility tends to increase welfare losses for a non-trivial range of values for parameter $\theta_{w}$. That finding holds regardless of the underlying source of shocks, and is also evident when all shocks are combined, as shown in Figure 6b. Export shocks are the only shock for which an increase in wage flexibility reduces welfare losses (locally) if wage rigidities are very strong to begin with. ${ }^{27}$ For most shocks (export shocks are again the exception), changes in the degree of wage rigidities imply quantitatively large relative changes on welfare losses. Thus, when all shocks are simultaneously active, the normalized welfare loss reaches a peak at $\theta_{w}=0.11$. At that value, the welfare loss is as much as 75 percent higher relative to its value under the baseline wage rigidity $\left(\theta_{w}=0.8\right)$. In absolute

\footnotetext{
${ }^{25}$ In contrast with the welfare analysis in section 4 , the present welfare analysis leaves the steady state distortions uncorrected, a more plausible assumption in our view. Nevertheless, we have also performed our baseline experiment (which evaluates the impact on welfare of varying the underlying degree of wage rigidity) based on a second order approximation around an efficient steady state (i.e., with an employment subsidy in place which remove the market power distortion in both labor and goods markets). Our results are virtually unchanged, quantitatively and qualitatively (findings available upon request).

${ }^{26}$ Note that up to first order the unconditional expected value of utility would be equal to its value in the deterministic steady state (and therefore $\lambda_{u}$ would be always equal to zero). See Schmitt-Grohe and Uribe $(2004,2007)$ for details on our approach.

${ }^{27}$ Experimentation with alternative calibrations suggest that the failure of export shocks to generate the inverted $\mathrm{U}$ pattern that obtains for other shocks is related to the assumed high indexation. In the absence of the latter the pattern is similar to that observed for all other shocks. Furthermore, in Appendix D, we report the results of a conditional welfare analysis to assess the role of wage flexibility in determining the welfare impact of one-off large shocks. In that case, welfare losses conditional on a large export shock turn out to be monotonically increasing in the degree of wage flexibility.
} 
terms, the peak welfare loss conditional on all shocks amounts to 0.26 percent of steady state consumption, a non-negligible value when compared to the welfare losses typically uncovered in related exercises in the literature.

Figure 7 displays, for the case of a currency union, welfare losses as a function of both the degree of price and wage rigidity, relative to the baseline case $\left(\theta_{p}=\theta_{w}=0.8\right)$. All shocks are assumed to be active. Clearly, the non-monotonic effect of higher wage flexibility on the welfare loss depends strongly on the underlying degree of price rigidity. If prices are sufficiently sticky, higher wage flexibility features the an inverted U-shaped effect on the welfare loss, with this effect being dampened as prices become more flexible. The figure also confirms that the potential welfare loss from increased wage flexibility is larger when prices are very sticky. In the limit, as prices become fully flexible, greater wage flexibility is always welfare improving though the gains appear to be relatively small in the case of a currency union considered here.

Figure 8 evaluates the effect on welfare losses of variations in the degree of wage rigidity, for all possible values of coefficient $\phi_{e}$ in the interest rate rule, corresponding to different strengths of the monetary policy response to deviations in the nominal exchange rate from its (implicit) target (again, with all shocks simultaneously active). This figure is best understood when looking at the two polar regimes: domestic inflation targeting $\left(\phi_{e}=0\right)$ and currency union $\left(\phi_{e}=1\right)$. In the former case, monetary policy is completely unconstrained from any exchange rate stabilization motive, and welfare losses are monotonically decreasing in the degree of wage flexibility. In the latter case, on the other hand, the non-monotonicity result obtained earlier reappears. Notice however that the non-monotonic effect of wage rigidity on welfare emerges also at intermediate values of $\phi_{e}$, corresponding to managed exchange rate regimes. It is also interesting to notice that, conditional on a sufficiently high degree of wage rigidity, welfare losses are generally monotonically decreasing in $\phi_{e}$, suggesting that if both nominal (price and wage) rigidities are in place, it is welfare improving to partially stabilize the nominal exchange rate. The reason for this is that in our economy, stabilizing the nominal exchange rate, and therefore the terms of trade, indirectly contributes to stabilizing CPI inflation. The latter effect, in turn, contributes to the stabilization of the wage markup and, hence, of wage inflation, whose variability has an important contribution to overall welfare losses, especially so when wages are very rigid. ${ }^{28}$

Figure 9 evaluates the robustness of our results to alternative settings of two parameters: the inverse (Frisch) labor supply elasticity $\varphi$ and the elasticity of substitution between domestic and foreign varieties, $\eta$. Two main results emerge. First, a lower labor supply elasticity (higher $\varphi)^{29}$ magnifies the peak in the welfare loss but it does not affect

\footnotetext{
${ }^{28}$ See Faia and Monacelli (2008) and Campolmi (2012) for the welfare benefit of (partially) stabilizing the nominal exchange rate in open economies with nominal rigidities.

${ }^{29}$ This is consistent with the micro evidence surveyed in Chetty et al. (2011), who recommend to calibrate the Frisch elasticity of aggregate hours below 1.
} 
significantly the value of $\theta_{w}$ at which the peak is reached). Most importantly, however, the non-monotonicity uncovered under the baseline calibration of $\varphi$ is preserved for variations in the latter of a plausible magnitude. Secondly, the assumed value of the trade elasticity is seen to be largely immaterial for the relationship between wage flexibility and welfare.

Finally, Figure 10 illustrates the role of the pass-through of marginal costs of imported varieties to their retail prices. More specifically, it plots the normalized welfare loss as a function of the degree of wage rigidities for two alternative cases: incomplete vs. complete pass-through. The incomplete pass-trough case corresponds to our baseline calibration. The complete pass-through case corresponds to a calibration with full price flexibility in import prices $\left(\theta_{F}=0\right)$ and no role of local labor in distribution $\left(\alpha_{F}=1\right)$. Note that the inverted- $U$ shape of the relation between wage rigidities and welfare losses is not qualitatively affected by the degree of pass-through. A higher degree of the latter, however, appears to dampen somewhat the marginal loss in welfare resulting from increased wage flexibility for plausible starting values of the latter.

In Appendixes $\mathrm{C}$ and $\mathrm{D}$ we provide some additional robustness analysis on the wefare impact of changes in the degree of wage rigidities. Thus, in Appendix C see we report results based on an extended version of our DSGE model featuring both traded and non-traded goods. Our main findings are virtually unchanged in the modified model. In Appendix D we analyze the welfare losses resulting from a one-off, large negative realization of the shock, as a function of the degree of wage rigidity. If anything, our results are even reinforced by this analysis, for two reasons. First, the absolute welfare loss numbers are higher (relative to our baseline unconditional welfare analysis presented in the main text). Second, and unlike our baseline unconditional welfare analysis, welfare losses are monotonically increasing in the degree of wage flexibility also in the case of an export demand shock.

\section{Related Literature}

Friedman (1953) is a classic reference on the interaction between nominal rigidities and the exchange rate regime. His case for flexible exchange rates rests on the usefulness of exchange rate adjustments as a substitute for price and wage adjustments, when the latter are difficult to bring about, in order to support a desirable or warranted change in the relative price of domestic and foreign goods. The presence of sufficiently flexible wages and prices as one of the criteria for the success of a currency union can be viewed as a corollary of Friedman's argument (see, e.g. European Commission (1990), Mongelli (2002)). More recent theoretical work focusing on the costs of downward nominal wage rigidity under an exchange rate peg can be found in Schmitt-Grohé and Uribe (2015), among others.

A number of contributions have analyzed the consequences and desirability of increased price and wage flexibility in the closed economy. Thus, DeLong and Summers (1986) use 
a model with staggered Taylor contracts to show that an increase in wage flexibility (as indexed by the responsiveness of wages to cyclical conditions) may be destabilizing due to a Mundell effect (i.e., the contractionary impact of falling prices, working through the expected real rate).

Using a New Keynesian model, Battarai, Eggertsson and Schoenlen (2014) study the conditions under which an increase in price flexibility may have destabilizing effects on output and employment. This will be the case if demands shocks are prevailing and interest rates do not respond strongly to inflation. By contrast, when supply shocks are dominant, greater price flexibility is destabilizing only if interest rates respond strongly to inflation. Also in the context of a closed economy, Galí (2013) addresses the same question with a focus on wage flexibility and its impact on welfare. He shows that an increase in wage flexibility may be welfare reducing if the interest rate is not too responsive to inflation. Both the Battarai et al. (2014) and Galí (2013) papers rely on a closed economy framework, and hence have nothing to say regarding the role of exchange rate policy.

The constraints on monetary policy imposed by a currency union are similar to those implied by a binding zero lower bound on the nominal interest rate. ${ }^{30}$ In that context, Eggertsson, Ferrero and Raffo (2014) raise a warning on the possible contractionary effects of structural reforms (modelled as favorable supply shocks), due to the increase in real interest rates resulting from deflationary pressures combined with an unresponsive nominal rate.

\section{Concluding Remarks}

Calling for greater wage flexibility as a way of insulating employment and output from shocks has become part of the conventional policy advice kit. For countries under a hard peg or belonging to a currency union, wage flexibility is seen as being even more valuable, given the impossibility of using the exchange rate as an adjustment mechanism.

The present paper calls into question that conventional wisdom. Using versions of an otherwise standard New Keynesian small open economy model, we have analyzed the impact of changes in the degree of wage rigidity on the economy's equilibrium properties, focusing on its welfare implications. Two findings stand out.

Firstly, the effectiveness of downward labor cost adjustments in stimulating employment is smaller in a currency union than under an autonomous, price stability-oriented monetary policy. This is due to the lack of an endogenous monetary policy response in the currency union.

Secondly, a (marginal) increase in wage flexibility often reduces welfare, and it is more likely to do so in economies under an exchange rate peg or an exchange rate-focused monetary policy. On the other hand, an increase in wage flexibility is more likely to

\footnotetext{
${ }^{30}$ Similar, but not identical, as made clear by Erceg and Lindé (2012).
} 
lead to a welfare improvement if it is accompanied by an increase in price flexibility as well. Our findings thus call into question the conventional view that wage flexibility is particularly desirable in a currency union. 


\section{References}

Adolfson, Malin, Stefan Laseen, Jesper Linde and Mattias Villani (2007): "Bayesian Estimation of an Open Economy DSGE Model with Incomplete Pass-Through," Journal of International Economics, vol. 72(2), 481-511.

Álvarez Luis J, Emmanuel Dhyne, Marco M. Hoeberichts, Claudia Kwapil, Hervé Le Bihan, Patrick Lünnemann, Fernando Martins, Roberto Sabbatini, Harald Stahl, Philip Vermeulen and Jouko Vilmunen (2005): "Sticky Prices in the Euro Area: A Summary of New Micro Evidence", ECB Working Paper n. 563 (December)

Barattieri Alessandro, Susanto Basu and Peter. Gottschalk (2014): "Some Evidence on the Importance of Sticky Wages," American Economic Journal: Macroeconomics, vol. 6(1), pages 70-101, January.

Bhattarai, Saroj, Gauti Eggertsson, and Raphael Schoenle (2014): "Is Increased Price Flexibility Stabilizing? Redux," mimeo.

Blanchard, Olivier J. and Jordi Galí (2007): "Real Wage Rigidities and the New Keynesian Model," Journal of Money, Credit, and Banking, supplement to volume 39, no. $1,35-66$.

Blanchard, Olivier J. and Jordi Galí (2010): "Labor Markets and Monetary Policy: A New Keynesian Model with Unemployment," American Economic Journal: Macroeconomics, 2 (2), 1-33.

Burriel, Pablo, Jesús Fernández-Villaverde, Juan F. Rubio-Ramírez (2009): "MEDEA: a DSGE Model for the Spanish Economy," SERIEs 1 (1-2), 175-243.

Burstein, Ariel, Martin Eichenbaum, and Sergio Rebelo (2007): "Modeling Exchange Rate Passthrough After Large Devaluations," Journal of Monetary Economics, vol. 54(2), pages 346-368.

Calvo, Guillermo and Carmen Reinhart (2002): "Fear of Floating," Quarterly Journal of Economics, 117(2),

Campa José and Linda Goldberg (2006): "Distribution Margins, Imported Inputs, and the Sensitivity of the CPI to Exchange Rates", NY Fed Staff Reports n. 247.

Campolmi, Alessia (2012): "Which Inflation to Target?: A Small Open Economy with Sticky Wages," Macroeconomic Dynamics, 1-30.

Chetty, Ray, Adam Guren, Day Manoli, and Andrea Weber (2011), "Are Micro and Macro Labor Supply Elasticities Consistent? A Review of Evidence on the Intensive and Extensive Margins", American Economic Review Papers and Proceedings, May.

Christoffel, Kai, Günter Coenen and Anders Warne (2008): "The New Area-Wide Model of the Euro Area. A Micro-founded Open-economy Model for Forecasting and Policy Analysis," ECB working paper no. 944.

Corsetti, Giancarlo and Luca Dedola (2005): "A Macroeconomic Model of International Price Discrimination," Journal of International Economics, vol. 67(1), pages 129155, September. 
De Long, J. Bradford and Lawrence H. Summers (1986): "Is Increased Price Flexibility Stabilizing?," American Economic Review 76(5), 1031-44.

Eggertsson, Gauti, Andrea Ferrero, and Andrea Raffo (2014): "Can Structural Reforms Help Europe?," Journal of Monetary Economics 61, 2-22.

Erceg, Christopher J., Dale W. Henderson, and Andrew T. Levin (2000): "Optimal Monetary Policy with Staggered Wage and Price Contracts," Journal of Monetary Economics vol. 46, no. 2, 281-314.

Erceg, Christopher, Christopher Gust and David López-Salido (2009): "The Transmission of Domestic Shocks in Open Economies," in J. Galí and M. Gertler (eds): International Dimensions of Monetary Policy, Chicago University Press.

Erceg, Christopher J., and Jesper Lindé (2012): "Fiscal Consolidation in an Open Economy," American Economic Review, 102(3): 186-91.

European Central Bank (2009): "Wage Dynamics in Europe: Final Report of the Wage Dynamics Network (WDN)"

European Commission (1990): One Market, One Money, Brussels.

Faia Ester and Tommaso Monacelli (2008): "Optimal Monetary Policy in a Small Open Economy with Home Bias," Journal of Money, Credit and Banking, vol. 40(4), $721-750,06$.

Farhi, Emmanuel, Gita Gopinath, and Oleg Itskhoki (2013): "Fiscal Devaluations," Review of Economic Studies 81 (2): 725-760.

Friedman, Milton (1953): "The Case for Flexible Exchange Rates," in M. Friedman, Essays in Positive Economics, Chicago University Press (Chicago, IL)

Galí, Jordi (2011): Unemployment Fluctuations and Stabilization Policies: A New Keynesian Perspective, MIT Press (Cambridge, MA).

Galí, Jordi (2013): "Notes for a New Guide to Keynes (I): Wages, Aggregate Demand and Employment," Journal of the European Econmic Association, 11(5), 973-1003.

Galí, Jordi (2015): Monetary Policy, Inflation and the Business Cycle. An Introduction to the New Keynesian Framework, second edition, Princeton University Press (Princeton, NJ).

Galí Jordi, Mark Gertler, David J. Lopez-Salido (2001): "European Inflation Dynamics", European Economic Review, vol. 45(7), 1237-1270.

Galí Jordi, Mark Gertler, David J. Lopez-Salido (2003): "Erratum", European Economic Review, vol. 47(4), 759-760.

Galí, Jordi and Tommaso Monacelli (2005): "Monetary Policy and Exchange Rate Volatility in a Small Open Economy," Review of Economic Studies, vol. 72, issue 3, 2005, 707-734.

Hall, Robert (2005): "Employment Fluctuations with Equilibrium Wage Stickiness," American Economic Review, 95(1), 50-64.

Monacelli, Tommaso (2005): "Monetary Policy in a Low Pass-Through Environment", Journal of Money Credit and Banking, Vol. 37, N. 6, 1047-1066. 
Mongelli, Francesco P. (2002): "New Views on the Optimum Currency Area Theory: What is EMU Telling Us?" ECB Working Paper no. 138.

Mundell, Robert (1961): "A Theory of Optimum Currency Areas," American Economic Review, 51(4), 657-665.

Nakamura, Emi and Jón Steinsson (2008): "Five Facts about Prices: A Reevaluation of Menu Cost Models," Quarterly Journal of Economics, vol. CXXIII, issue 4, 1415-1464.

Reinhart, Carmen M. (2000): "Mirage of Floating Exchange Rates." American Economic Review, 90(2): 65-70.

Schmitt-Grohe, Stephanie and Martin Uribe (2004): "Solving Dynamic General Equilibrium Models Using a Second-Order Approximation to the Policy Function." Journal of Economic Dynamics and Control, 28 (4), 755-775.

Schmitt-Grohe, Stephanie and Martin Uribe (2007): "Optimal, Simple, and Implementable Monetary and Fiscal Rules", Journal of Monetary Economics 54, September, 1702-1725.

Schmitt-Grohe Stephanie and Martin Uribe (2015): "Downward Nominal Wage Rigidity, Currency Pegs, and Involuntary Unemployment," Journal of Political Economy, forthcoming.

Shimer, Robert (2005): "The Cyclical Behavior of Equilibrium Unemployment and Vacancies," American Economic Review, 95(1), 25-49.

Shimer, Robert (2010): "Wage Rigidities and Jobless Recoveries," mimeo. 


\begin{tabular}{|c|c|c|}
\hline Parameter & Description & Value \\
\hline \multicolumn{3}{|c|}{ Baseline Model } \\
\hline $\bar{\varphi}$ & Curvature of labor disutility & 2.2 \\
\hline$\alpha$ & Decreasing returns to labor & 0.26 \\
\hline$\epsilon_{w}$ & Elasticity of substitution (labor) & 4.3 \\
\hline$\epsilon_{p}$ & Elasticity of substitution (goods) & 3.8 \\
\hline$\theta_{p}$ & Calvo index of price rigidities & 0.8 \\
\hline$\theta_{w}$ & Calvo index of wage rigidities & 0.8 \\
\hline$v$ & Openness & 0.3 \\
\hline$\beta$ & Discount factor & 0.99 \\
\hline$\rho_{i}$ & Persistence of exogenous processes & 0.9 \\
\hline \multicolumn{3}{|c|}{ DSGE Model } \\
\hline 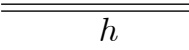 & Consumption habits & $\overline{0.564}$ \\
\hline$\eta$ & Trade elasticity of substitution & $\{0.5,1,2\}$ \\
\hline$\alpha_{F}$ & Decreaing returns to labor (imports retail) & 0.62 \\
\hline$\theta_{F}$ & Calvo index of import price rigidity & 0.528 \\
\hline$\chi_{w}$ & Indexation of wages & 0.635 \\
\hline$\chi_{p}$ & Indexation of domestic prices & 0.417 \\
\hline$\chi_{f}$ & Indexation of import prices & 0.480 \\
\hline$\delta$ & Depreciation rate of capital & 0.025 \\
\hline$\omega_{k}$ & Investment adjustment cost & 5.169 \\
\hline \multicolumn{3}{|c|}{$\begin{array}{c}\text { Table 2. DSGE Model: Estimated Shock Processes } \\
\end{array}$} \\
\hline Parameter & Description & Value \\
\hline$\rho_{a}$ & Domestic technology shock: Persistence & 0.74 \\
\hline$\sigma_{a}$ & Domestic technology shock: Standard deviation & n $\quad 0.0064$ \\
\hline$\rho_{z}$ & Domestic demand shock: Persistence & 0.6 \\
\hline$\sigma_{z}$ & Domestic demand shock: Standard deviation & 0.029 \\
\hline$\rho_{1}^{*}$ & Export shock: Persistence & 0.9 \\
\hline$\sigma_{1}^{*}$ & Export shock: Standard deviation & 0.0057 \\
\hline$\rho_{2}^{*}$ & World interest rate shock: Persistence & 0.9 \\
\hline$\sigma_{2}^{*}$ & World interest rate shock: Standard deviation & 0.001 \\
\hline
\end{tabular}



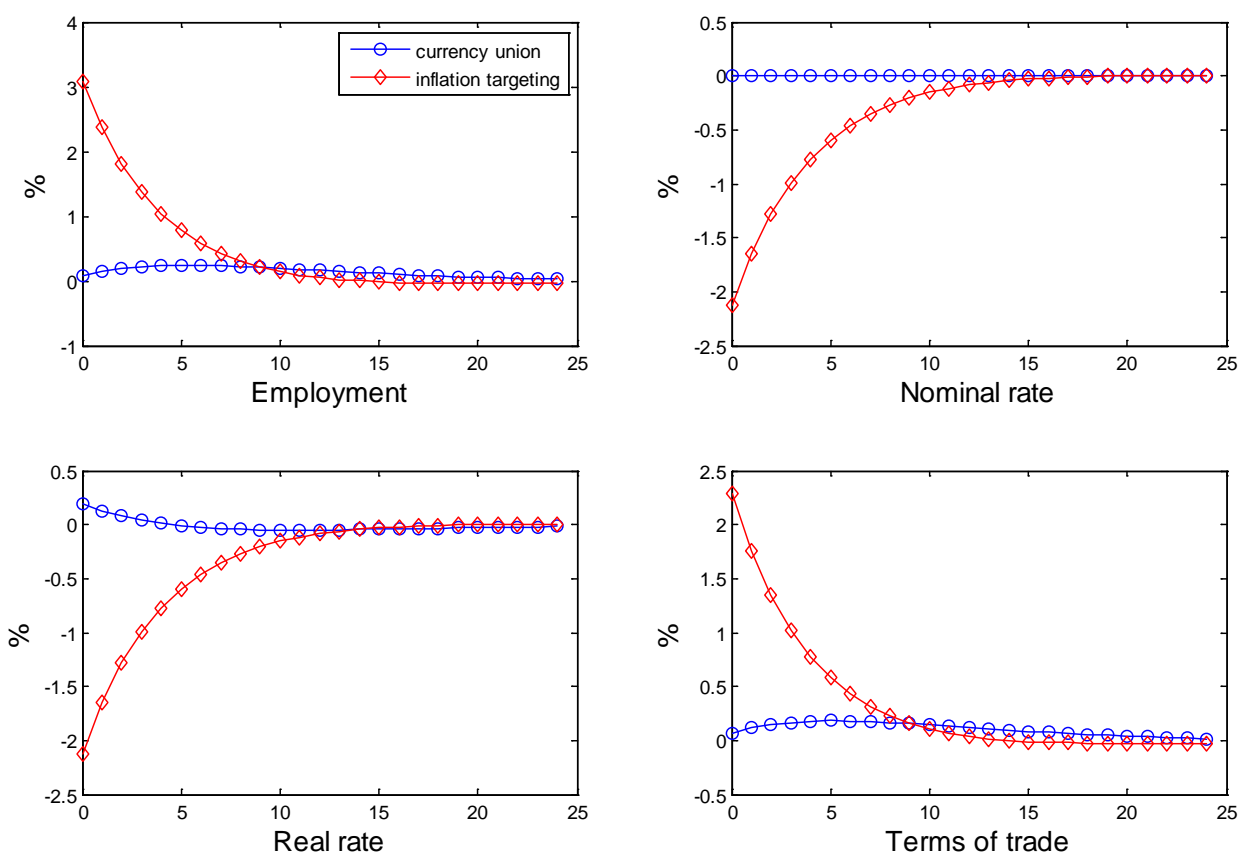

Figure 1a. Dynamic Responses to a Temporary Payroll Tax Cut
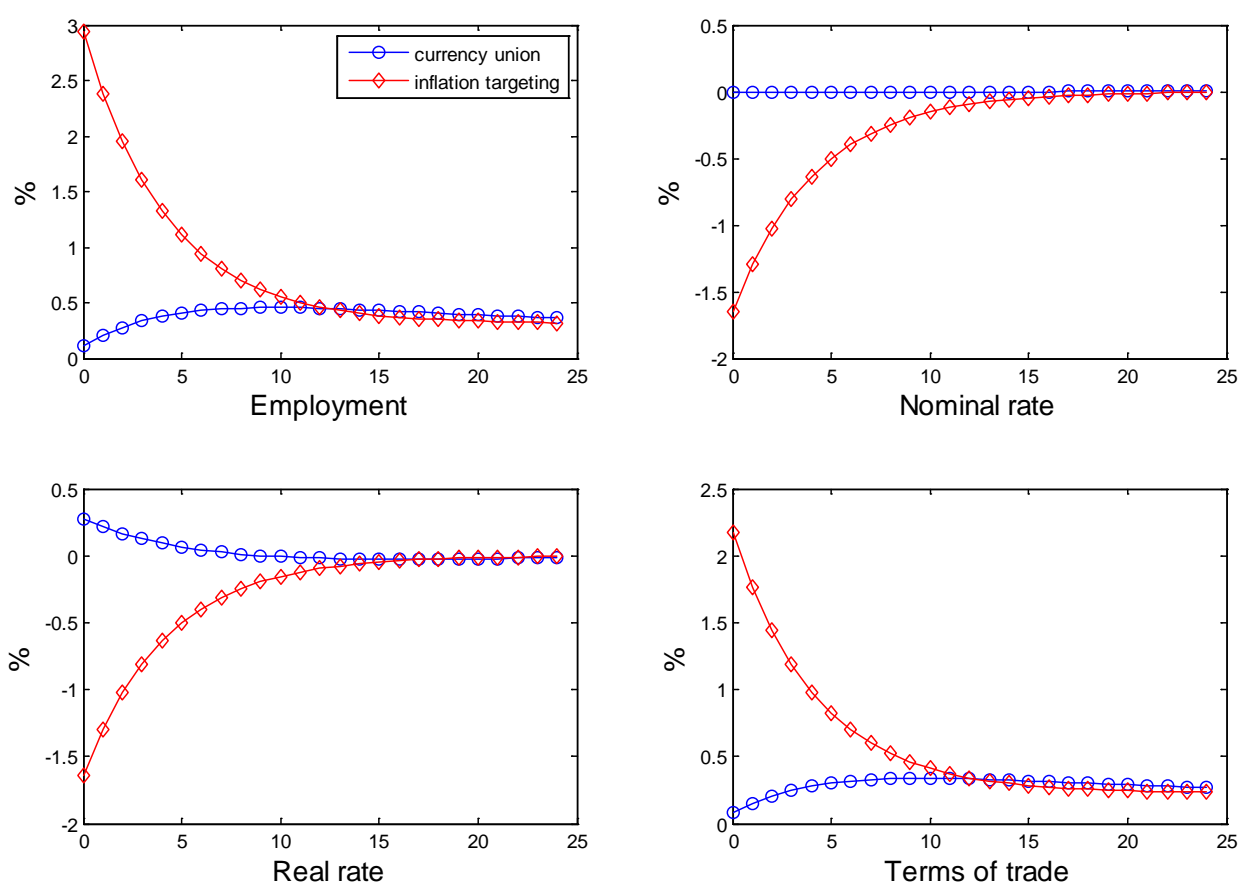

Figure 1b. Dynamic Responses to a Permanent Payroll Tax Cut 

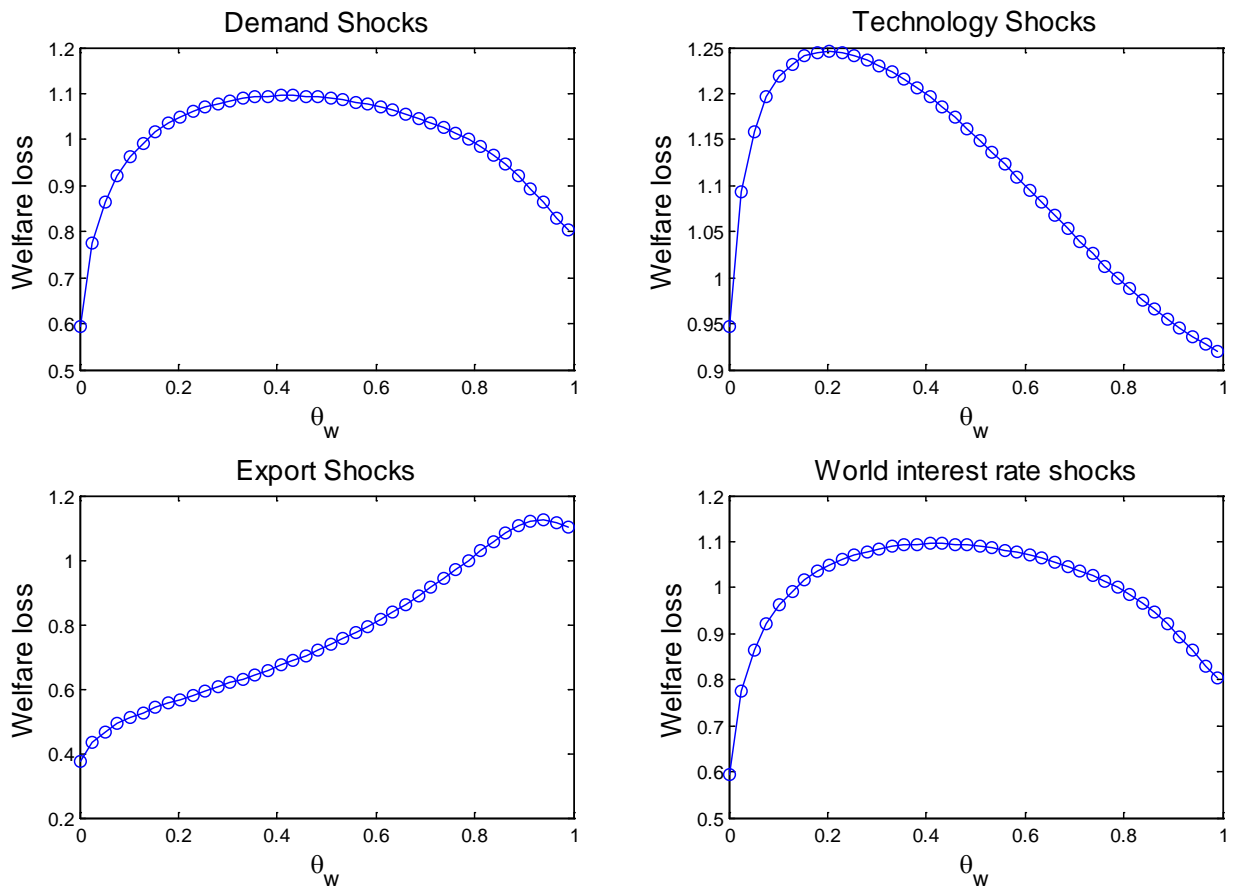

Figure 2. Wage Rigidities and Welfare in a Currency Union

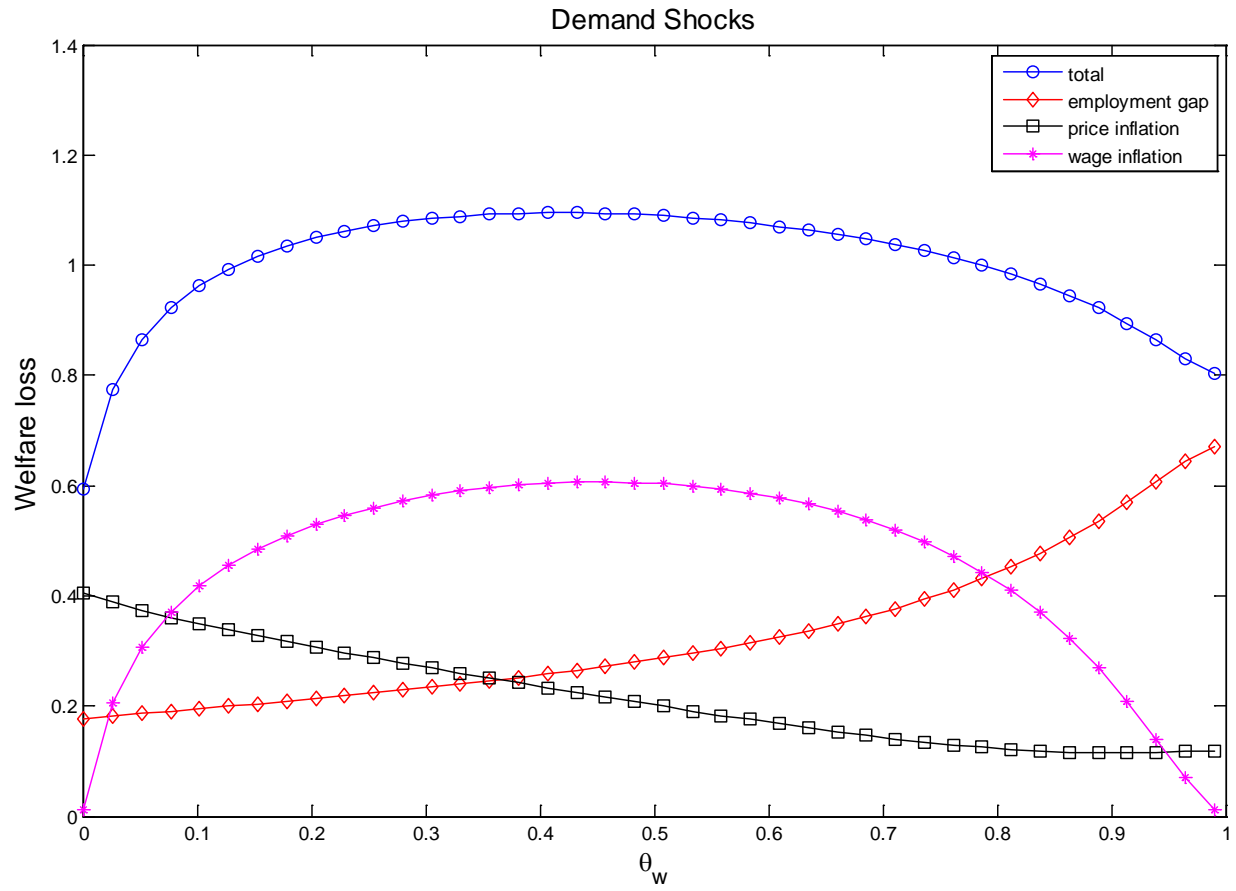

Figure 3. Wage Rigidities in a Currency Union: Welfare Components 

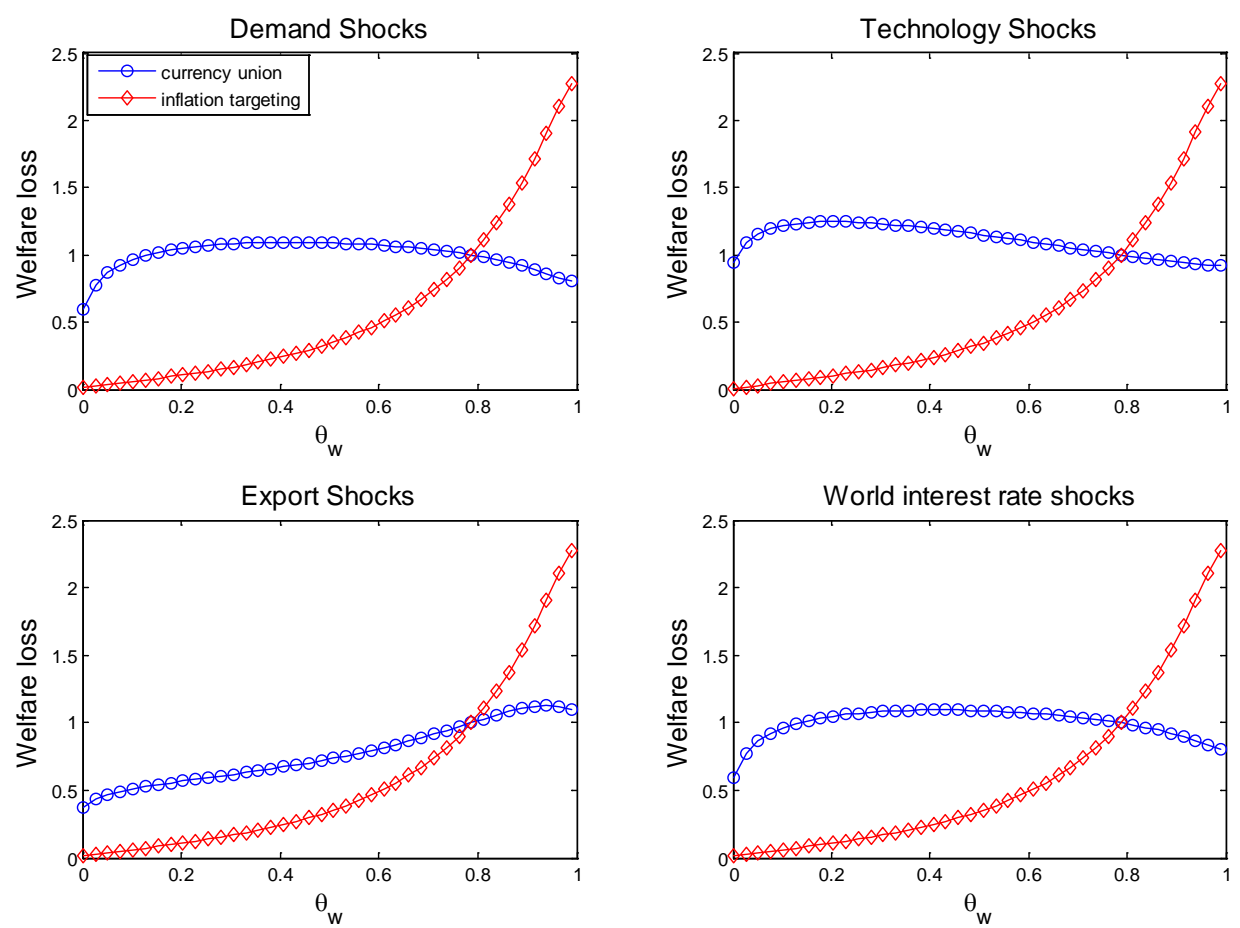

Figure 4. Wage Rigidities and Welfare: Currency Union vs. Inflation Targeting
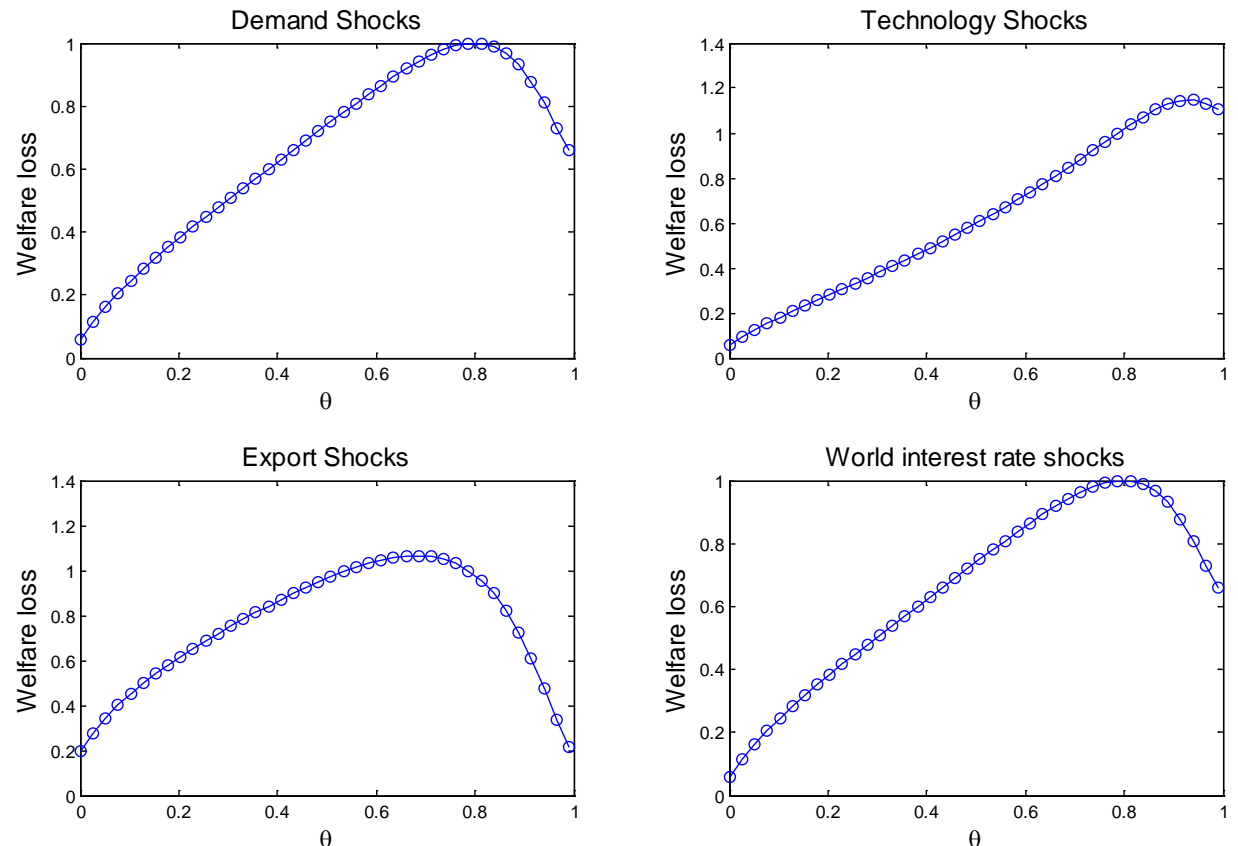

Figure 5. Nominal Rigidities and Welfare in a Currency Union 

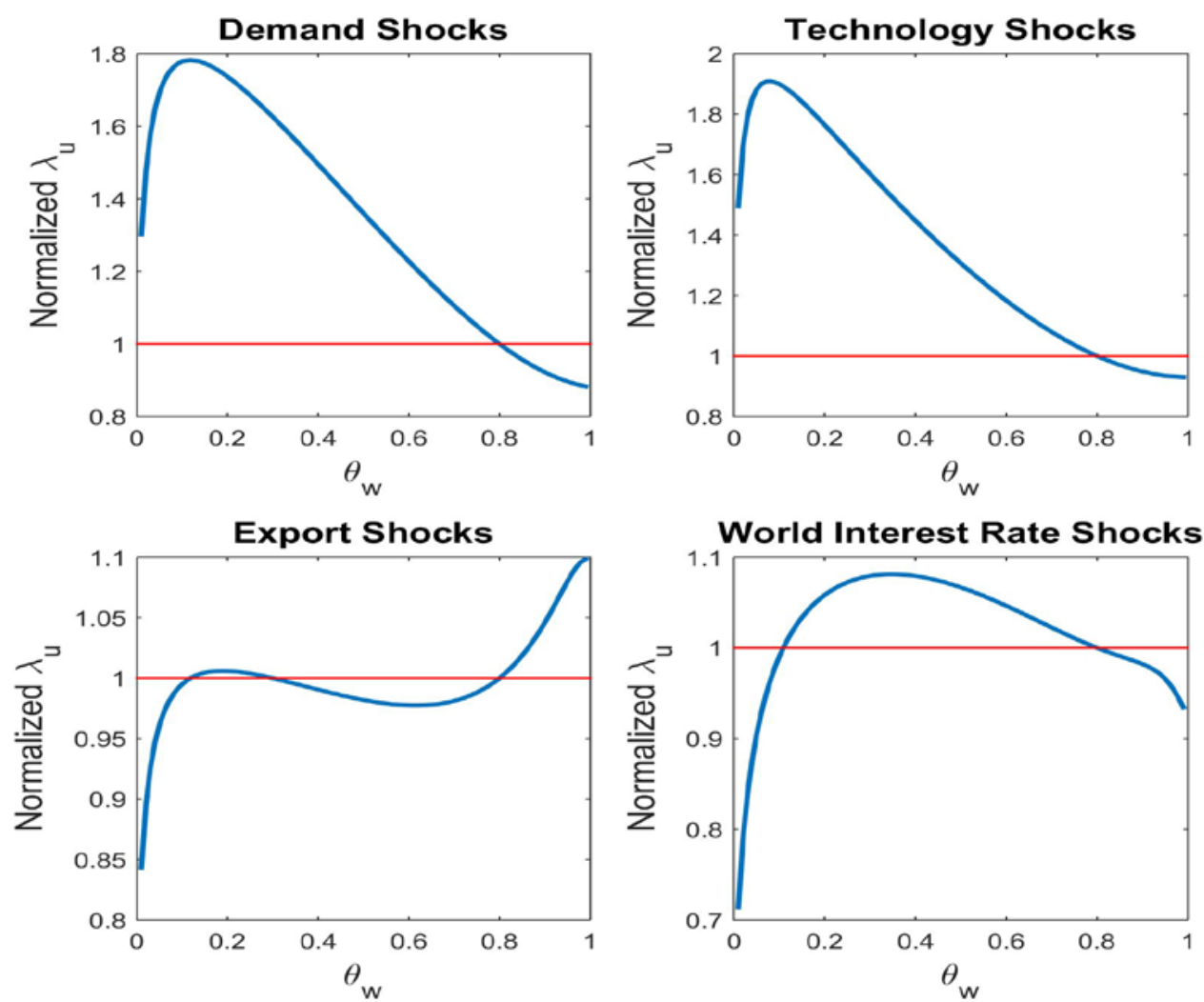

Figure 6a. Wage Rigidities and Welfare in a Currency Union: DSGE Model

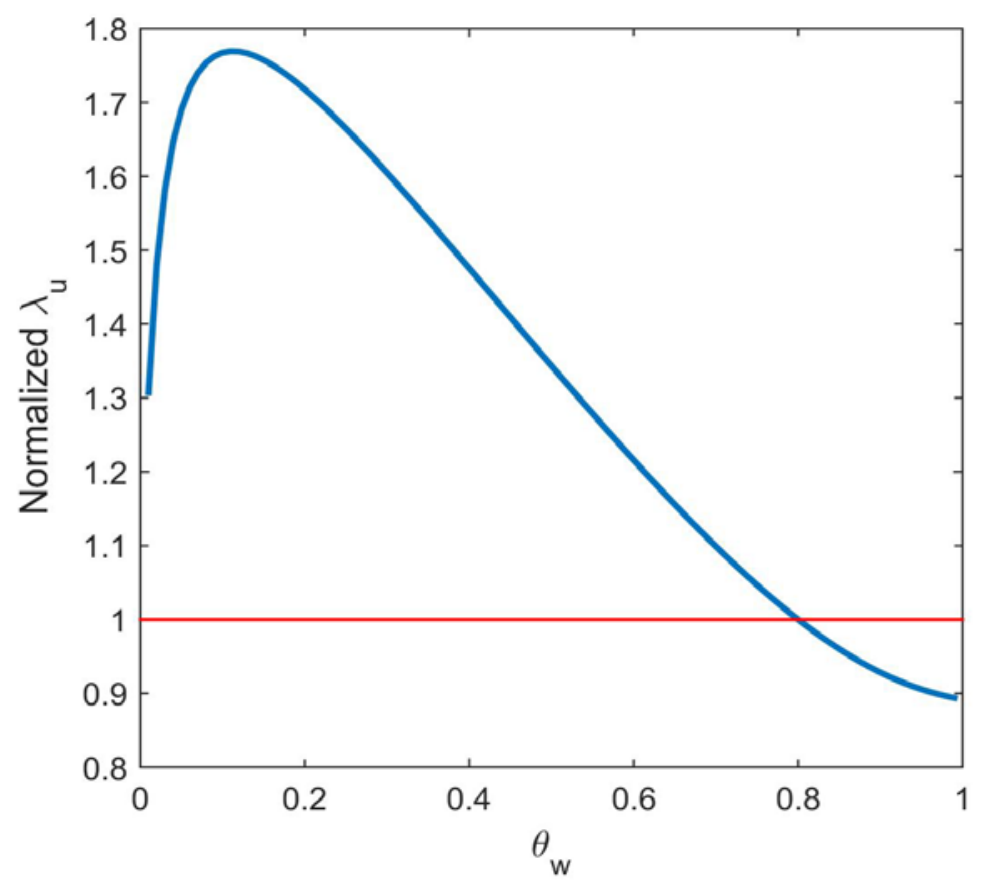

Figure 6b. Wage Rigidities and Welfare in a Currency Union: DSGE Model + All Shocks 


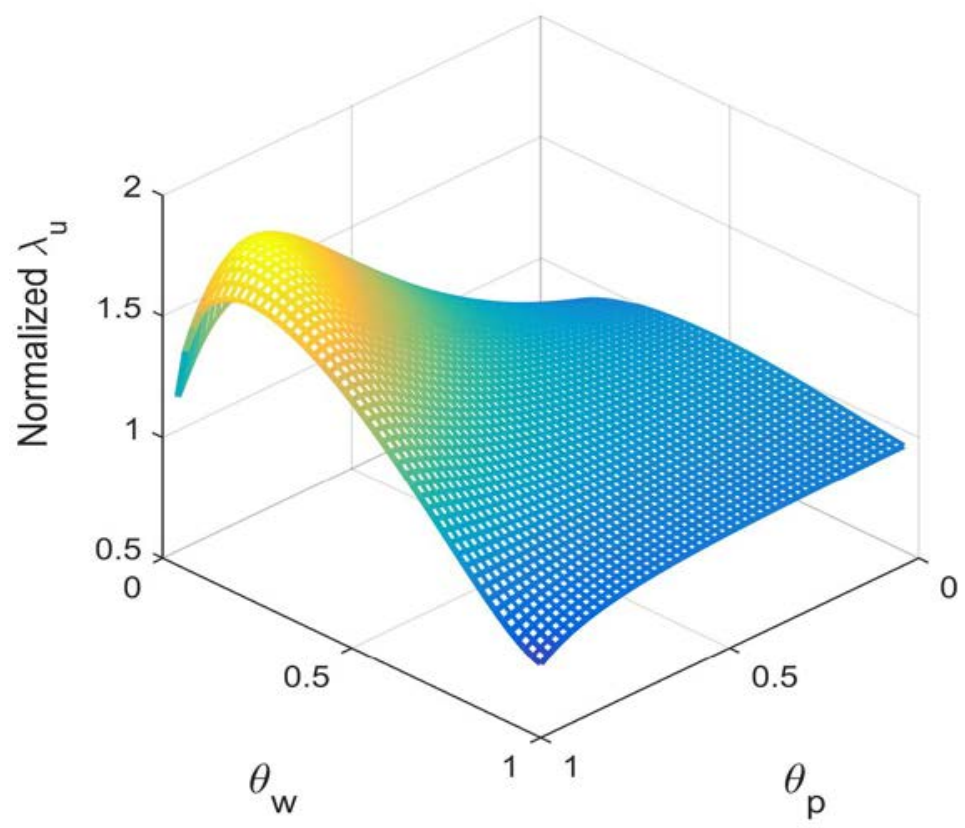

Figure 7. Nominal Rigidities and Welfare in a Currency Union: DSGE Model

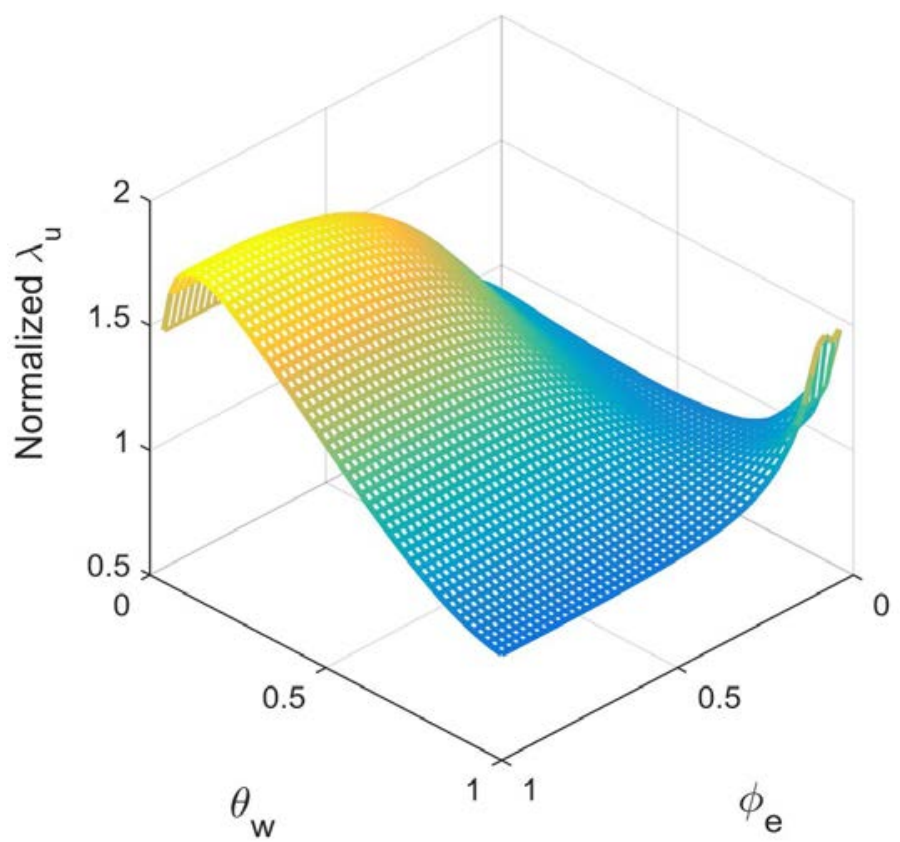

Figure 8. Wage Rigidities, Exchange Rate Regimes and Welfare: DSGE Model 

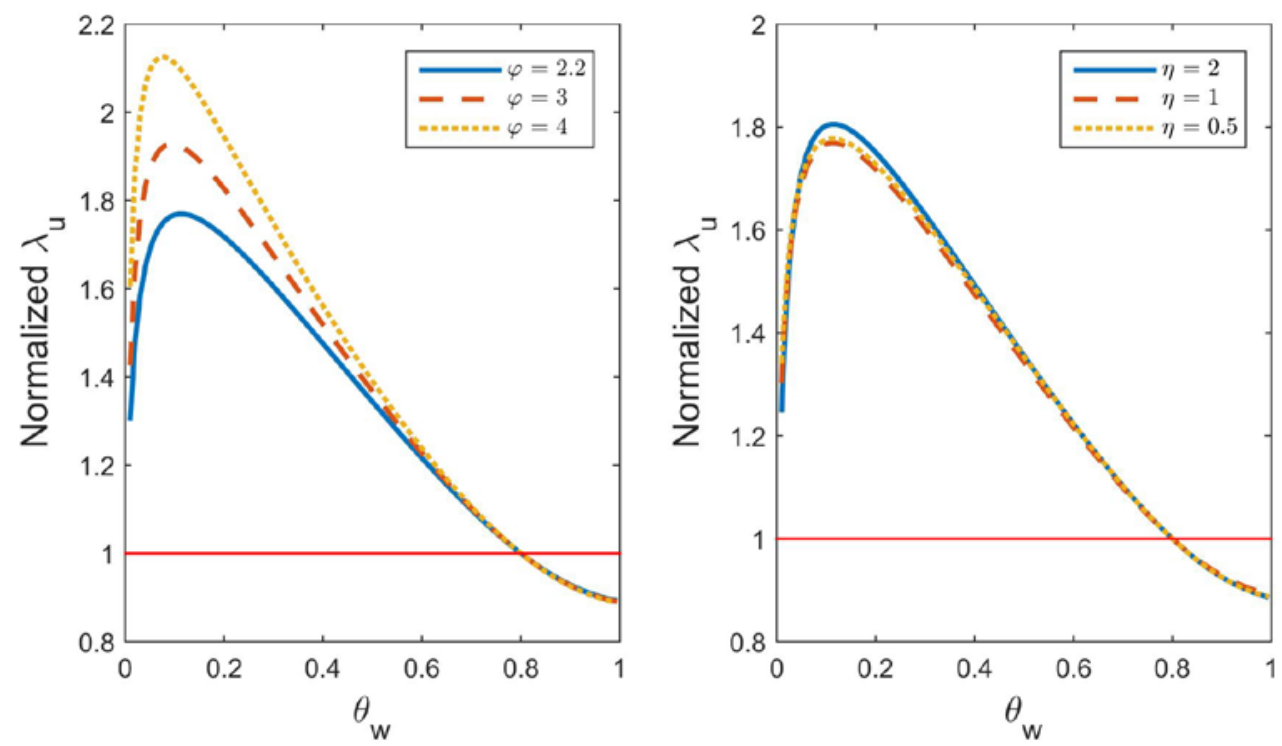

Figure 9. Wage Rigidities and Welfare in a Currency Union: DSGE Model The Role of Labor Supply Elasticity (left) and the Trade Elasticity (right)

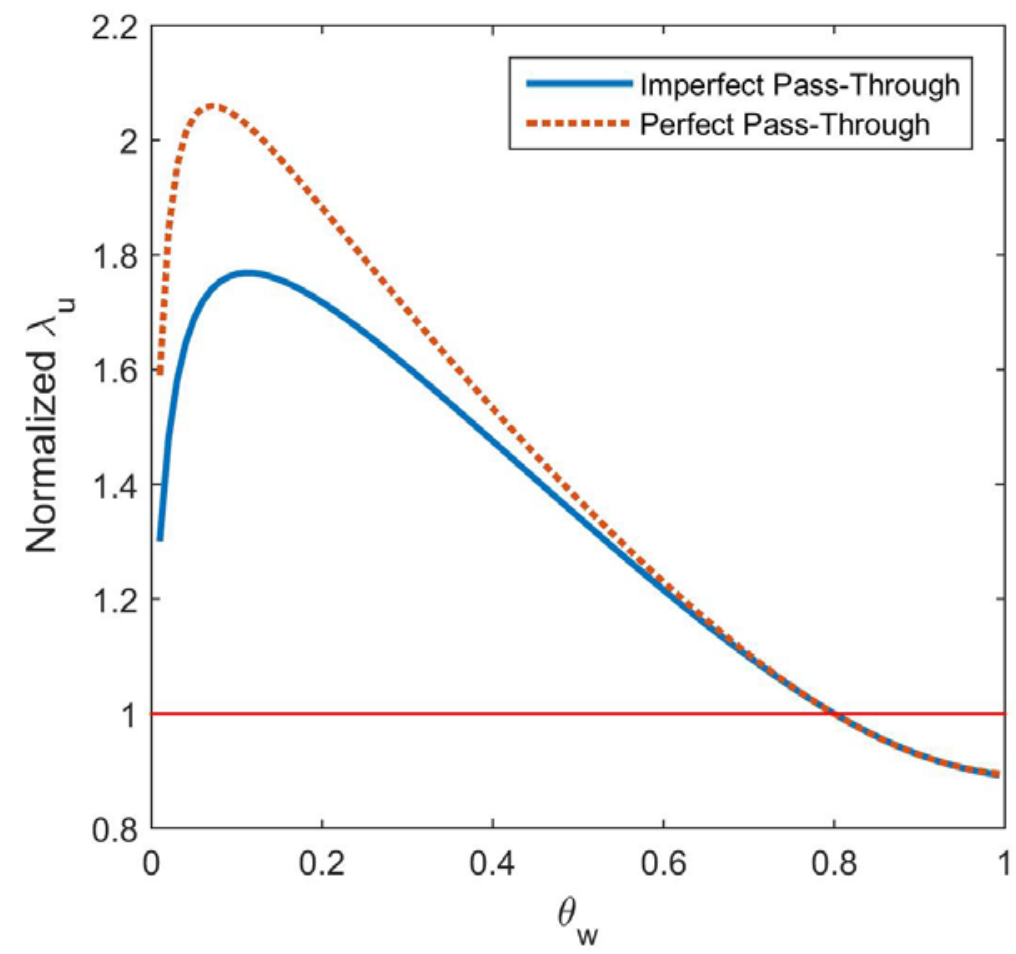

Figure 10. Wage Rigidities and Welfare in a Currency Union: DSGE Model The Role of the Exchange Rate Pass-Through 